Biogeosciences, 10, 1097-1116, 2013

www.biogeosciences.net/10/1097/2013/

doi:10.5194/bg-10-1097-2013

(C) Author(s) 2013. CC Attribution 3.0 License.

\title{
Impact of open-ocean convection on particle fluxes and sediment dynamics in the deep margin of the Gulf of Lions
}

\author{
M. Stabholz ${ }^{1,2}$, X. Durrieu de Madron ${ }^{1}$, M. Canals ${ }^{2}$, A. Khripounoff ${ }^{3}$, I. Taupier-Letage ${ }^{4}$, P. Testor ${ }^{5}$, S. Heussner ${ }^{1}$, \\ P. Kerhervé ${ }^{1}$, N. Delsaut ${ }^{1}$, L. Houpert ${ }^{1}$, G. Lastras $^{2}$, and B. Dennielou ${ }^{6}$ \\ ${ }^{1}$ CEFREM, CNRS, Université de Perpignan Via Domitia, UMR 5110, 52 avenue Paul Alduy, 66860 Perpignan, France \\ ${ }^{2}$ GRC Geociències Marines, Departament d'Estratigrafia, Paleontologia i Geociències Marines, Universitat de Barcelona, \\ C/Martí i Franqués, s/n, 08028 Barcelona, Spain \\ ${ }^{3}$ IFREMER, Département EEP/LEP, Centre de Bretagne BP70, 29280 Plouzané Cedex, France \\ ${ }^{4}$ Aix-Marseille Université, Université du Sud Toulon-Var, CNRS/INSU, IRD, MIO, UMR 6117, UM 110, \\ 83507 La Seyne sur Mer, France \\ ${ }^{5}$ LOCEAN, CNRS, IRD, Université Pierre et Marie Curie, MNHN, UMR 7159, 4 place Jussieu, 75252 Paris, France \\ ${ }^{6}$ IFREMER, Unité de Recherche Géosciences Marines, BP70, 29280 Plouzané Cedex, France
}

Correspondence to: M. Stabholz (marionstabholz@ hotmail.com)

Received: 1 August 2012 - Published in Biogeosciences Discuss.: 18 September 2012

Revised: 7 January 2013 - Accepted: 20 January 2013 - Published: 19 February 2013

\begin{abstract}
The deep outer margin of the Gulf of Lions and the adjacent basin, in the western Mediterranean Sea, are regularly impacted by open-ocean convection, a major hydrodynamic event responsible for the ventilation of the deep water in the western Mediterranean Basin. However, the impact of open-ocean convection on the flux and transport of particulate matter remains poorly understood. The variability of water mass properties (i.e., temperature and salinity), currents, and particle fluxes were monitored between September 2007 and April 2009 at five instrumented mooring lines deployed between 2050 and 2350-m depth in the deepest continental margin and adjacent basin. Four of the lines followed a NWSE transect, while the fifth one was located on a sediment wave field to the west. The results of the main, central line SC2350 ("LION") located at $42^{\circ} 02.5^{\prime} \mathrm{N}, 4^{\circ} 41^{\prime} \mathrm{E}$, at 2350 $\mathrm{m}$ depth, show that open-ocean convection reached midwater depth $(\approx 1000$-m depth) during winter 2007-2008, and reached the seabed $(\approx 2350$-m depth) during winter 2008 2009. Horizontal currents were unusually strong with speeds up to $39 \mathrm{~cm} \mathrm{~s}^{-1}$ during winter 2008-2009. The measurements at all 5 different locations indicate that mid-depth and near-bottom currents and particle fluxes gave relatively consistent values of similar magnitude across the study area except during winter 2008-2009, when near-bottom fluxes abruptly increased by one to two orders of magnitude. Partic-
\end{abstract}

ulate organic carbon contents, which generally vary between 3 and $5 \%$, were abnormally low $(\leq 1 \%)$ during winter 2008 2009 and approached those observed in surface sediments $(\approx$ $0.6 \%$ ). Turbidity profiles made in the region demonstrated the existence of a bottom nepheloid layer, several hundred meters thick, and related to the resuspension of bottom sediments. These observations support the view that open-ocean deep convection events in the Gulf of Lions can cause significant remobilization of sediments in the deep outer margin and the basin, with a subsequent alteration of the seabed likely impacting the functioning of the deep-sea ecosystem.

\section{Introduction}

Albeit the deep-sea is the largest ecosystem on Earth, not much is known about how it is affected by changes in environmental conditions controlling the cycling of biogeochemical compounds, the distribution of deep-sea habitats or the functioning of ecosystems. Dense water convection represents, among physical processes influencing circulation in the deep-sea, one of the few linking the surface ocean to the deep ocean and, ultimately, to the seabed. Dense water formation, which can occur in both coastal areas and open sea regions, and the subsequent export of newly formed 
waters to depth through dense shelf water cascading (DSWC) and open-ocean convection (OOC), have mainly been studied from a physical oceanography viewpoint (Marshall and Schott, 1999; Ivanov et al., 2004).

The Mediterranean Sea constitutes a remarkable marine domain where exchanges with the Atlantic Ocean through the Strait of Gibraltar and deep-water formation drive thermohaline circulation in the different sub-basins and in the whole basin, in turn controlling the distribution of biogeochemical compounds and thus shaping the ecosystem (MERMEX Group, 2011). Studies conducted in the Mediterranean Sea have shown how significant the role of dense deep-water formation and associated winter vertical mixing could be. Sinking dense water carries large amounts of organic matter, including particulate and dissolved carbon (POC and DOC, respectively), from the productive surface layer to depths below. Therefore, the removal of POC and DOC from surface waters and their injection to the deep Mediterranean Sea are strongly affected by deep-water formation and the vertical mixing that comes with it (Avril, 2002; Canals et al., 2006; Santinelli et al., 2010). Subsequently, DSWC and OOC lead to the formation of new, ventilated deep waters in the Mediterranean Basin. The occurrence of an efficient transfer of particles from the surface layer to depth linked to peak fluxes because of coastal and open-ocean dense water formation has been shown by several authors in the Gulf of Lions and in the nearby Ligurian Sea, both in the northwestern Mediterranean Sea, in winter 1999, 2005 and 2006 (Heussner et al., 2006; Sanchez-Vidal et al., 2009; Miquel et al., 2011). It has also been shown that high fluxes captured by deep-sea sediment traps correlate with the concentrations of large particles. The main export of such large particles occurs in winter during episodes of enhanced vertical mixing (Durrieu de Madron et al., 1999; Stemmann et al., 2002).

Some authors have also assessed the role of E-SE storms in transferring particulate matter to the deep Gulf of Lions (Palanques et al., 2009; Sanchez-Vidal et al., 2012). The former inferred that the high particle fluxes observed in the outer margin and basin during the two winter periods between November 2003 and April 2005 were related to lateral inputs from the adjacent shelf due to the occurrence of strong E-SE storms or DSWC, while the latter evidenced that most organic matter transferred to depths below came from the shelf following a large eastern storm in late December 2008 and that it was transferred to depths below associated with the finest fraction of particle fluxes. However, none of these two studies addressed the effects on particle fluxes of open-ocean deep convection that occurred at the same time. Open-ocean deep convection in the western Mediterranean Basin and the formation of western Mediterranean Deep Water (WMDW) have been investigated by numerous authors (see, for instance, Marshall and Schott, 1999 and references therein) following the MEDOC Group pioneer work in the Gulf of Lions (MEDOC Group, 1970). However, very few studies have focused to date on the impacts of OOC over matter and energy transfers, deep-water sediment dynamics and, ultimately, the deep ecosystem. Guidi-Guilvard (2002) showed that variations of the hyperbenthic communities in the Ligurian Sea resulted from both near-bottom currents and particle flux variability. Pusceddu et al. (2010) reported and compared the main impacts and ecosystemic effects produced by DSWC and OOC in the Gulf of Lions and the Aegean Sea, the latter in the northeastern Mediterranean Sea. These authors found that increased contents of particulate organic matter in deepsea sediments diminished benthic abundance and changes of benthic biodiversity. Martín et al. (2010) showed that sediment resuspension and abnormally high near-bottom particulate fluxes occurred in the Ligurian Sea during a severe OOC event in winter 2005-2006. Puig et al. (2012) inferred, after an analysis of hydrological data of the last two decades that intense deep-water formation in winters 1999, 2005 and 2006 caused the formation of a thick bottom nepheloid layer that eventually extended over the entire western Mediterranean deep basin.

With the exception of the above-mentioned studies, it becomes quite clear that in the Gulf of Lions particulate fluxes and their sedimentary and ecosystemic impacts in the inner and mid-margin, including submarine canyons and adjacent open slopes, have received substantially more attention than in the deep outer margin adjacent to the Algero-Balearic Basin. We can also state that all studies emphasize the strong interannual variability of matter and energy transfers and impacts associated with Eastern storms and to DSWC and OOC reaching the seabed in the Gulf of Lions margin and adjacent deep basin.

Some modeling exercises on sediment transfer and vertical mixing in the Gulf of Lions have also been carried out. They have stressed, first, the impact of DSWC on the transfer of particulate matter to the deep margin and basin (Ulses et al., 2008) and, second, that both DSWC and OOC will likely experience a reduction in their frequency and intensity during the 21 st century as a result of an increasing ocean stratification and the weakening of the thermohaline circulation because of the warming of ocean waters (Herrmann et al., 2008; Somot et al., 2008). The impact of global warming on the frequency and intensity of large storms is more uncertain (Ulbrich et al., 2009; Marcos et al., 2011; Young et al., 2011).

In this paper, we aim at characterizing the impact of OOC on particulate fluxes, and at inferring its potential imprint on sediment dynamics, after 20 months of continued observation of the water mass structure, hydrodynamics and mass fluxes in the Gulf of Lions deep outer margin and adjacent basin. By comparison with previous studies, we illustrate a number of scenarios on the effects of OOC over sediment transport, and discuss its potential effects on bathypelagic biological activity and benthic habitats. 


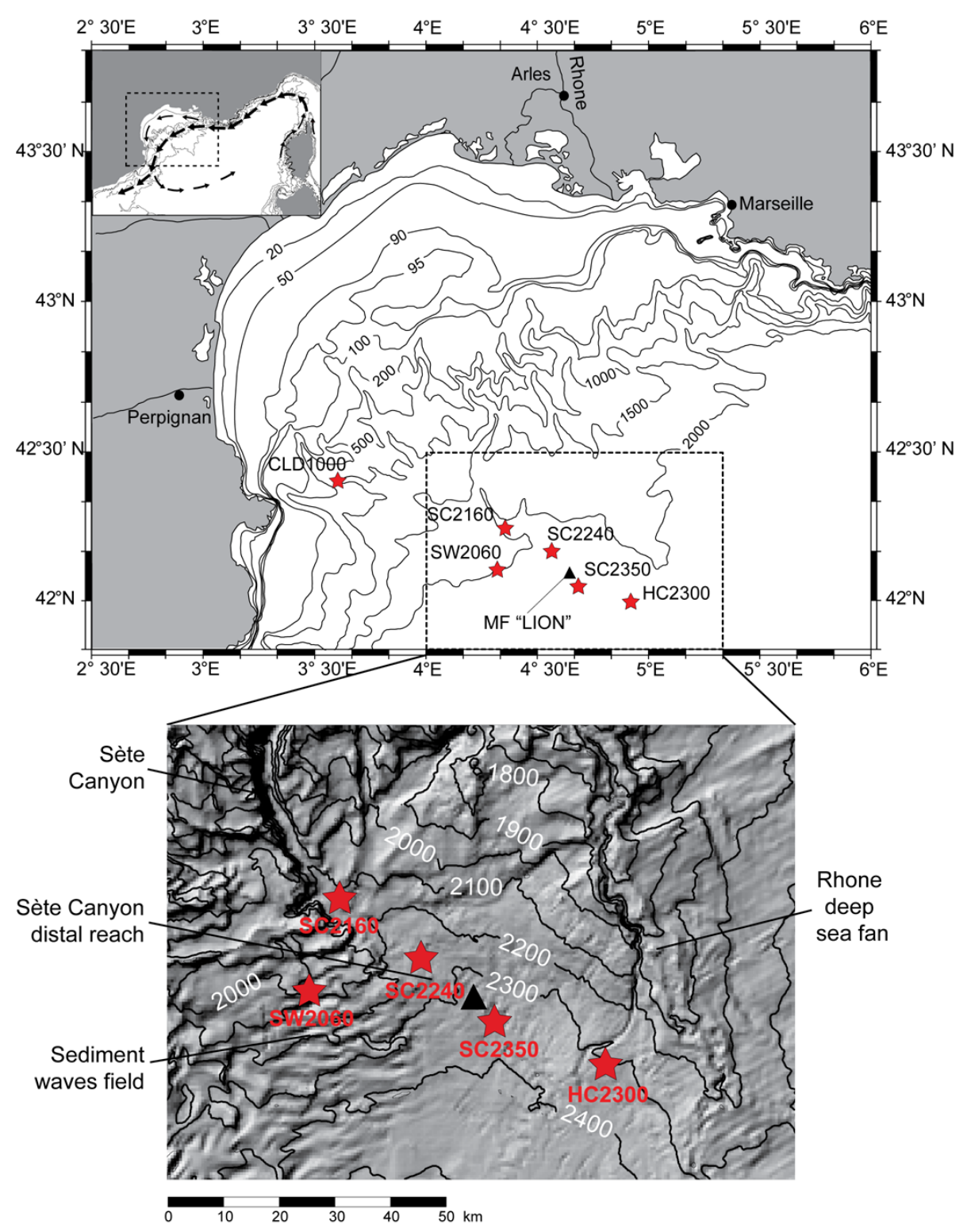

Fig. 1. Map of Gulf of Lions shelf, slope and rise in the northwestern Mediterranean Sea. Red stars indicate the position of the mooring lines (LDC1000, SW2060, SC21060, SC2240, SC2350, HC2300) and the black triangle indicates the position of the Météo-France buoy (MF-LION). The shelf and open sea regions are separated by a permanent circulation flowing cyclonically along the slope (the Northern Current). The eastwards flowing extension of the permanent circulation in the southern part of the Gulf of Lions forms the cyclonic gyre that embeds the open-ocean convection region. A zoom of the mooring array area shows the major seabed features based on a shaded image build from the digital terrain map (Berné et al., 1999).

\section{General setting}

The deep outer margin of the Gulf of Lions and the adjacent basin are bounded by Corsica and Sardinia to the east and the NE opening of the Valencia Trough and Balearic Islands to the west. To the north, a rather complex topography forms the continental slope of the gulf, which is incised by numerous submarine canyons (Fig. 1). The largest of these canyons extend towards the deep margin and basin at depths from 2000 to $2400 \mathrm{~m}$. Particularly prominent are the $\mathrm{N}-\mathrm{S}$ ori- ented Sète Canyon, towards which all canyons of the western Gulf of Lions converge, and the Petit-Rhône canyon-channel system feeding the Rhône deep-sea fan, with a neo-channel feeding the youngest lobe, or neo-fan (Droz and Bellaiche, 1985; Droz et al., 2001).

Oceanic circulation in the northwestern Mediterranean Sea is characterized by a large-scale cyclonic pattern (see insert in Fig. 1). The northern branch of this cyclonic gyre, the Northern Current, flows westwards and south-westwards 
along the continental slope and continues southward through the Ibiza Channel. Part of it however flows eastward between the Balearic Islands and Corsica along the North Balearic Front (for a review see Millot and Taupier-Letage, 2005). Associated with this cyclonic gyre, a dome-like structure develops that reaches its highest point around $42^{\circ} \mathrm{N}-5^{\circ} \mathrm{E}$. Dense water formation in the Gulf of Lions occurs owing to the effect of frequent and durable northwesterly (Tramontane) and northerly (Mistral) continental winds in winter. Dense deep waters form in two distinct locations: offshore, over the deep margin and adjacent basin, in a preconditioned area (Marshall and Schott, 1999 and references therein), and over the continental shelf (Durrieu de Madron et al., 2005; Ulses et al., 2008).

OOC results from a combination of regional circulation (i.e., the cyclonic gyre involving the rising of intermediate and deep water masses) and meteorology (i.e., winddriven cooling and mixing of surface waters) that predisposes the water column to locally overturn (Marshall and Schott, 1999). Moreover, the N-S oriented positive relief formed by the Rhône deep-sea fan also contributes to trap the above waters following the Taylor column effect, thus prolonging the exposure of surface waters to the cooling action of the atmosphere (Madec and Crepon, 1991). Vertical convection mixes surface water with warmer but saltier intermediate water and deepens the mixed layer, which can eventually reach the seabed (> 2000-m depth) (Mertens and Schott, 1998). In the last $7 \mathrm{yr}$ bottom-reaching convection over the outer margin and adjacent basin was observed in 2005, 2006, 2009, 2010 and 2011 (López-Jurado et al., 2005; Houpert et al., 2012). According to Marshall and Schott (1999), OOC is a three-stage process: (i) the "preconditioning phase" results from the wind-driven mixing of the surface layer and the erosion of the seasonal thermocline during autumn; (ii) the "mixing phase" in winter is characterized by a gradual deepening of the surface mixed layer and by the possible homogenization of the whole water column describing a large chimney-like structure; and (iii) the "sinking and spreading phase" takes place at the end of the winter when the restratification of the surface layer is due to reduced wind forcing and increased solar heating. Testor and Gascard (2006) studied the post-convection spreading phase in the northwestern Mediterranean Sea and showed that numerous eddies drifted away from the convection area and advected newly formed deep waters far away from the source region.

In situ current measurements on the deep slope and in the basin are scarce. Near-bottom currents in the deep basin are generally rather low $\left(<10 \mathrm{~cm} \mathrm{~s}^{-1}\right)$, though substantially higher velocities (up to $50 \mathrm{~cm} \mathrm{~s}^{-1}$ ) have been occasionally measured during wintertime (Millot and Monaco, 1984; Palanques et al., 2009). Such currents are believed to be capable of reworking loose sediments, in an area where sedimentation rates are particularly low (i.e., $0.01-0.05 \mathrm{~cm} \mathrm{yr}^{-1}$ after Miralles et al., 2005).

\section{Material and methods}

\subsection{Mooring lines}

Five mooring lines, deployed from September 2007 to April 2009, constituted the observational design in our study. They were contained within a circle of about $30 \mathrm{~km}$ in radius centred at $42^{\circ} 04^{\prime} \mathrm{N}, 4^{\circ} 38^{\prime} \mathrm{E}$, which is the position of the Météo-France meteorological buoy "LION" (Fig. 1). The 5 lines were positioned on distinctive features of the Gulf of Lions' continental rise and basin. Lines SC2160, SC2240 and SC2350 were located at different water depths (last four digits) along the distal reach of Sète Canyon (SC). The westernmost line (SW2060) was located on a large sediment wave field west of Sète Canyon (SW) (Jallet and Giresse, 2005) atop of the Pyrenean Canyon Deep Sedimentary Body (Canals, 1985; Alonso et al., 1991), also named Pyreneo-Languedocian Sedimentary Ridge (Berné et al., 1999) to the south of the lower reach of Cap de Creus Canyon. The easternmost line, HC2300, is part of the HYDROCHANGE (HC) network (http://www.ciesm.org/marine/programs/hydrochanges.htm) and was deployed on the Rhône neo-fan lobe, south of the neo-channel (see Sect. 2: General setting).

The overall recording and sampling period lasted from September 2007 to April 2009. Relevant data on instruments for the different mooring lines are summarized in Table 1. SW2060 and SC2350 lines were operated by CEFREM/LOCEAN, SC2160 and SC2240 lines by IFREMER, and HC2300 line by MIO. All lines were equipped with current meters between 20 and $45 \mathrm{~m}$ above bottom (mab). With the only exception of the HC2300 eastern line, all lines were also equipped with a sequential sediment trap between 25 and 55 mab. The central line SC2350 ("LION") extended upward more than $2 \mathrm{~km}$ from the seafloor at $2350 \mathrm{~m}$ up to $150 \mathrm{~m}$ below sea surface. It included an additional sediment trap and current meter pair at mid-water depth ( 1000-m depth). SC2350 and HC2300 lines were equipped with additional CTD sensors (see Sect. 3.2: Hydrological time series and profiles).

The dynamics of the mooring lines were assessed using the Mooring Design and Dynamics software (Dewey, 1999) and validated by comparing the modeled deepening of the line to the pressure sensor records of current meters and/or CTD probes. Tilting and deepening of the mooring lines were insignificant during periods of weak current velocity $\left(<11 \mathrm{~cm} \mathrm{~s}^{-1}\right)$ in spring and summer, and increased during periods of stronger currents (up to $39 \mathrm{~cm} \mathrm{~s}^{-1}$ ), mostly recorded during winter 2008-2009. For near-bottom instruments, the maximum deepening and tilting were about $3 \mathrm{~m}$ and $15^{\circ}$, respectively. For the long SC2350 line, maximum deepening and tilting of the instruments at the subsurface and mid-depth were about $390 \mathrm{~m}$ and $23^{\circ}$, and $250 \mathrm{~m}$ and $15^{\circ}$, respectively. 
Table 1. Location, deployment periods, instrument type and placement within each line, and sampling rates of current meters and sediment traps in the mooring lines considered in this paper.

\begin{tabular}{|c|c|c|c|c|c|c|c|}
\hline & Site & SW2060 & $\mathrm{SC} 2160$ & $\mathrm{SC} 2240$ & \multicolumn{2}{|c|}{ SC2350 "Lion" } & $\mathrm{HC} 2300$ \\
\hline \multirow{5}{*}{\multicolumn{2}{|c|}{$\begin{array}{l}\text { Latitude } \\
\text { Longitude } \\
\text { Water depth }(\mathrm{m}) \\
\text { Deployment periods }\end{array}$}} & $42^{\circ} 07^{\prime} \mathrm{N}$ & $42^{\circ} 15^{\prime} \mathrm{N}$ & $42^{\circ} 10^{\prime} \mathrm{N}$ & \multicolumn{2}{|l|}{$42^{\circ} 02.5^{\prime} \mathrm{N}$} & $41^{\circ} 59^{\prime} \mathrm{N}$ \\
\hline & & $4^{\circ} 19^{\prime} \mathrm{E}$ & $4^{\circ} 21^{\prime} \mathrm{E}$ & $4^{\circ} 33^{\prime} \mathrm{E}$ & \multicolumn{2}{|l|}{$4^{\circ} 41^{\prime} \mathrm{E}$} & $4^{\circ} 55^{\prime} \mathrm{E}$ \\
\hline & & 2060 & 2160 & 2240 & \multicolumn{2}{|l|}{2350} & 2305 \\
\hline & & 1 Apr 2008 to 23 Sep 2008 & \multirow{2}{*}{\multicolumn{2}{|c|}{$\begin{array}{l}28 \text { Mar } 2008 \text { to } 29 \text { Aug } 2008 \\
1 \text { Sep } 2008 \text { to } 5 \text { Apr } 2009\end{array}$}} & \multirow{2}{*}{\multicolumn{2}{|c|}{$\begin{array}{l}15 \text { Sep } 2007 \text { to } 16 \text { Mar } 2008 \\
1 \text { Apr } 2008 \text { to } 23 \text { Sep } 2008 \\
25 \text { Sep } 2008 \text { to } 25 \text { Mar } 2009\end{array}$}} & 27 May 2007 to 29 Jul 2008 \\
\hline & & 25 Sep 2008 to 25 Mar 2009 & & & & & $29 \mathrm{Jul} 2008$ to 7 May 2009 \\
\hline \multirow[t]{5}{*}{ Current meter } & Type & RDI & Aanderaa & Aanderaa & Aanderaa & Nortek & Mors \\
\hline & & $\mathrm{ADCP}$ & RCM8 & RCM8 & RCM9 & Aquadopp & MC360 \\
\hline & Depth (m) & 2010 & 2115 & 2195 & 1005 & 2325 & 2285 \\
\hline & Altitude (mab) & 50 & 45 & 45 & 1345 & 25 & 20 \\
\hline & Sampling interval & $30 \mathrm{~min}$ & $30 \mathrm{~min}$ & $30 \mathrm{~min}$ & $30 \mathrm{~min}$ & $30 \mathrm{~min}$ & $2 \mathrm{~h}$ \\
\hline \multirow[t]{4}{*}{ Sediment trap } & Type & $\begin{array}{l}\text { Technicap } \\
\text { PPS3 }\end{array}$ & $\begin{array}{l}\text { Technicap } \\
\text { PPS5 }\end{array}$ & $\begin{array}{l}\text { Technicap } \\
\text { PPS5 }\end{array}$ & $\begin{array}{l}\text { Technicap } \\
\text { PPS3 }\end{array}$ & $\begin{array}{l}\text { Technicap } \\
\text { PPS3 }\end{array}$ & n. a. \\
\hline & Depth (m) & 2005 & 2135 & 2215 & 1000 & 2320 & n. a. \\
\hline & Altitude (mab) & 55 & 25 & 25 & 1350 & 30 & n. a. \\
\hline & Sampling interval & 15 days & 7 or 9 days & 7 or 9 days & 15 days & 15 days & n. a. \\
\hline
\end{tabular}

Table 2. Location, water depth and sampling interval of Sea-Bird 37 CTD sensors at mooring lines SC2350 "Lion" and HC2300.

\begin{tabular}{llrrrrr}
\hline \multicolumn{1}{l}{ Site } & \multicolumn{3}{c}{ SC2350 “Lion” } & HC2300 \\
\hline \multirow{2}{*}{ CTD } & Type & SBE 37 & SBE 37 & SBE 37 & SBE 37 & SBE 37 \\
& & SMP & SMP & SMP & SM & SMP \\
\cline { 2 - 6 } & Depth (m) & 158 & 690 & 1507 & 2315 & 2287 \\
Altitude (mab) & 2192 & 1660 & 843 & 25 & 18 \\
Sampling & 6 min & 6 min & 6 min & 6 min & $1 \mathrm{~h}$ \\
interval & & & & & \\
\hline
\end{tabular}

In addition, the mooring line LDC1000 deployed since 1993 on the Lacaze-Duthiers Canyon slope at 1000-m depth was used as a slope reference to observe dense shelf water cascading events (Heussner, 2006). Only potential temperature time series from September 2007 to April 2009 was used in this study.

\subsection{Hydrological time series and profiles}

Conductivity, temperature and depth time series were recorded at the SC2350 and HC2300 stations with SBE 37SMP instruments (Table 2). Four CTD sensors were clamped at 158,690,1507, and 2315-m depth on the SC2350 line, and one CTD sensor was clamped at 2287-m depth on the HC2300 line. RBR1000 temperature loggers were also clamped on the upper kilometer of the SC2350 line between SBE 37SMP CTD sensors to increase the vertical resolution (resulting in 8 sensors in the first deployment and up to 21 sensors in the third deployment). CTD data were corrected for offset and drift using pre- and post-deployment calibrations performed by Sea-Bird Electronics.

Additional comparisons between instruments were performed with respect to CTD casts carried out prior and after the turnarounds of mooring lines. CTD casts were done using a SBE 911 probe occasionally equipped with a Seapoint backscatter sensor at $880 \mathrm{~nm}$ to measure turbidity. The range of the turbidity sensor was $0-5$ formazine turbidity units (FTU). ITS-90 was utilized for temperature. Temperature records from current meters were used at 500 and 1000 $m$ depth on the LDC1000 line.

\subsection{Current meter time series}

Current speed and direction were recorded with mechanical or acoustic current meters (Table 1). The sampling interval was set to $30 \mathrm{~min}$ or $2 \mathrm{~h}$. Due to a breaking at the base of SC2350 line during the second recovery and the loss of the current meter, no near-bottom current data were obtained at this site for the third deployment period (September 2008 to March 2009).

\subsection{Sediment trap time series}

Settling particles were collected with automated sediment traps. SC2160 and SC2240 lines held Technicap PPS5 coneshaped trap with a $1 \mathrm{~m}^{2}$ mouth covered with a honeycomb baffle (with cells $10 \mathrm{~cm}$ deep and $1 \mathrm{~cm}$ in diameter). PPS5 traps were equipped with 24 collecting bottles. The sampling interval was set to 7 days during the first deployment (28 March 2008 to 29 August 2008) and to 9 days during the second deployment (1 September 2008 to 5 April 2009); see also in Table 1. SW2060 and SC2350 lines held Technicap PPS3 cylindro-conical traps with a $0.125 \mathrm{~m}^{2}$ mouth and 12 collecting bottles. Sampling interval was set to 15 days during the different deployments (15 September 2007 to 16 March 2008 for line SC2350 only and 1 April 2008 to 23 September 2008; 25 September 2008 to 25 March 2009 for SW2060 and SC2350 lines; see also in Table 1). Collection efficiency of sediment traps depends on the flow 
Table 3. Characteristics of surficial $(0-0.5 \mathrm{~cm})$ sediment from cores collected in April 2009 at three different coring sites. Classification according to the Udden-Wentworth scale in 3 major categories: clay $<4 \mu \mathrm{m}, 4 \mu \mathrm{m} \leq$ silt $<63 \mu \mathrm{m}$, sand $>63 \mu \mathrm{m}$

\begin{tabular}{lrrr}
\hline Site & SW2060 & SC2240 & $\begin{array}{r}\text { SC2350 } \\
\text { "Lion" }\end{array}$ \\
\hline Bottom depth (m) & 2070 & 2229 & 2326 \\
Clay (\%) & 15.8 & 26.3 & 17.2 \\
Silt (\%) & 64.5 & 62.9 & 51.7 \\
Sand (\%) & 19.7 & 10.8 & 31.1 \\
POC (\%) & 0.57 & 0.59 & 0.56 \\
CF-CS sedimentation & 0.07 & 0.22 & 0.15 \\
rate (cm yr & & & \\
\hline
\end{tabular}

velocity, the trap shape and aspect ratio (height/diameter), the tilt, and the settling velocity of particles (Baker et al., 1988; White, 1990; Buesseler, 1991 and reference therein). Despite hydrodynamic biases associated with intermittent strong currents and tilt, and different trap designs (conical and baffled PPS5 versus unbaffled cylindric PPS3), the similarities of temporal variability of near-bottom fluxes at the different sites suggests that data are robust enough to draw conclusions on the overall seasonal and interannual variability of downward particle fluxes in the study area.

For all traps, the collecting bottles were filled with a $3-5 \%(v / v)$ formaldehyde solution in filtered seawater deployment. After recovery, large "swimmers" were removed by hand, and the remaining particles were filtered through glass-fiber filters for carbon analysis and $0.45 \mu \mathrm{m}$ pore size membranes (Millipore or Nuclepore) for total mass flux determination, rinsed with Milli-Q purified water and dried at $40^{\circ} \mathrm{C}$. Particulate organic carbon concentrations in trap samples were measured with a LECO WR12 elemental analyzer (SC2160 and SC2230 samples) or LECO CN 2000 analyzer (SW2050 and SC2350 samples) after removing carbonates with a $2 \mathrm{~N} \mathrm{HCl}$ solution (Weliky, 1983).

\subsection{Sediment cores}

Sediment cores were sampled in April 2009 at three locations close to our experimental site with a multicorer using $10 \mathrm{~cm}$ in diameter, $30 \mathrm{~cm}$ long Plexiglas tubes. Each core was sliced in different layers of $0.5 \mathrm{~cm}$ down to $5 \mathrm{~cm}$, and of $1 \mathrm{~cm}$ downcore $(>5 \mathrm{~cm})$, stored in polyethylene plastic bags and preserved at $4{ }^{\circ} \mathrm{C}$ until analysis. Organic carbon and grain size were analysed on surface sediment samples $(0-0.5 \mathrm{~cm})$, whereas the entire core was used to estimate apparent sedimentation rate (Table 3 ).

POC content was measured with a LECO CN 2000: aliquots of freeze-dried, ground sediment were reacted with a $2 \mathrm{~N} \mathrm{HCl}$ solution to remove carbonates prior to analysis (Weliky, 1983).
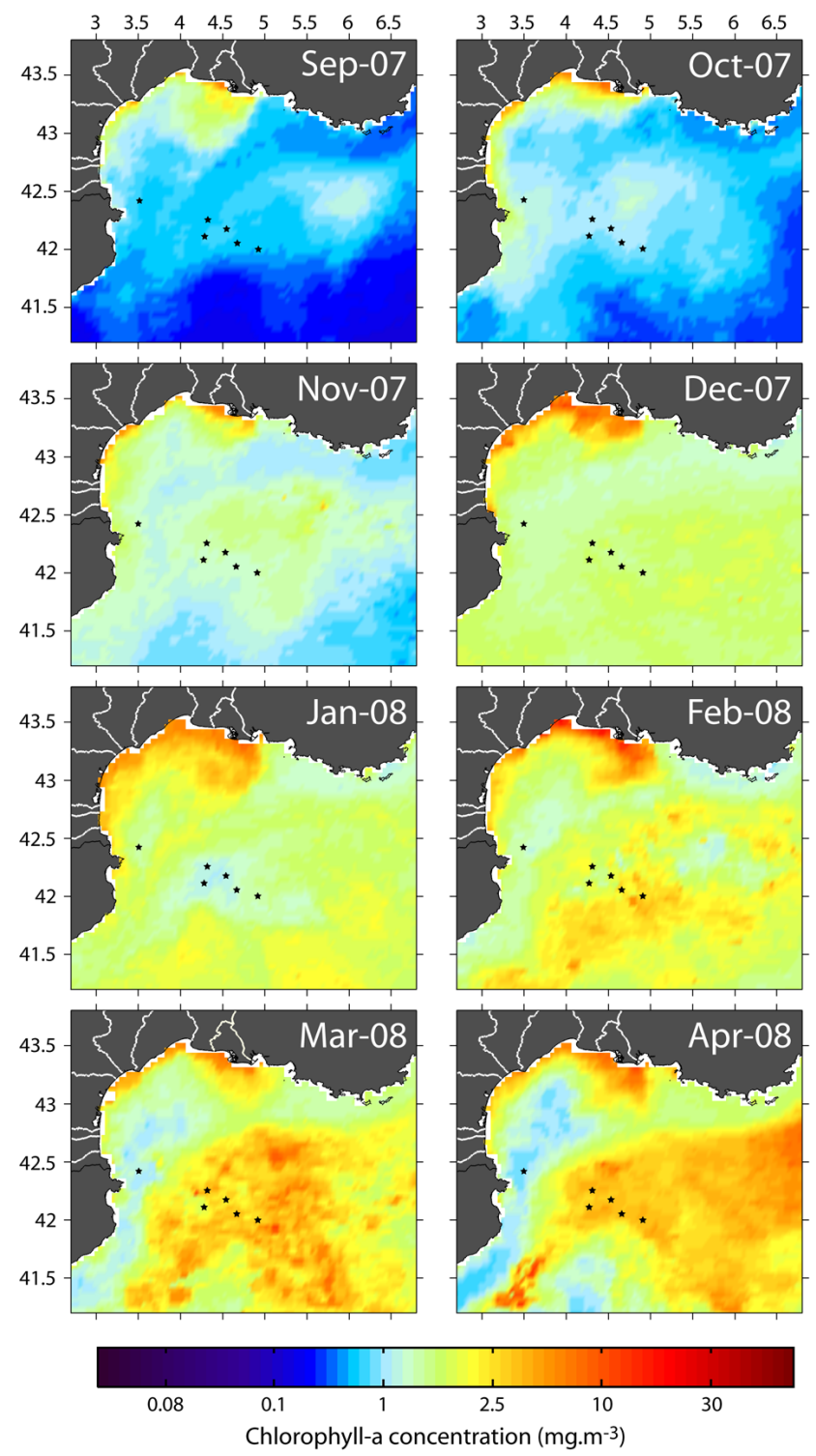

Fig. 2. Monthly averaged MODIS-Aqua $4 \mathrm{~km}$ surface chl $a$ images from September 2007 to April 2008. Black stars indicated the location of the mooring sites. Satellite data were downloaded from NASA's Giovanni portal (http://disc.sci.gsfc.nasa.gov/giovanni).

Grain size analyses were undertaken using a Malvern Mastersizer 2000 laser diffraction particle size analyzer; aliquots of fresh raw top sediment were prepared in $500 \mathrm{~mL}$ of water to obtain suspensions in a suitable dispersion to carry out the measurements. A small ultrasonic treatment was applied to break up loosely held agglomerates. For each sample 2 dispersions were prepared and the measurement was repeated 3 times until a stable dispersion had been achieved. Measurable sizes ranged from $50 \mathrm{~nm}$ to $1000 \mu \mathrm{m}$, and the results were then classified on the basis of textural features according to the Udden-Wentworth scale in three main categories: clay $<4 \mu \mathrm{m}, 4 \mu \mathrm{m} \leq$ silt $<63 \mu \mathrm{m}$ and $63 \mu \mathrm{m}<$ sand $<1 \mathrm{~mm}$. 
Apparent sedimentation rates were determined by alphamass spectroscopy of freeze-dried, ground sediment. ${ }^{210} \mathrm{~Pb}$ and ${ }^{210} \mathrm{Po}$ extraction was made by complete acid digestion (successively $\mathrm{HNO}_{3}, \mathrm{HNO}_{3}-\mathrm{HClO}_{4}, \mathrm{HCl}$ and $\mathrm{HF}$ ), followed by spontaneous deposition of polonium on a silver disc (Flynn, 1968). The disc was placed between $\mathrm{ZnS}(\mathrm{Ag}$ ) phosphors and counted on a total alpha counter (Hallden and Harley, 1960). A subsequent deposition and counting, some 6 months later, recorded ${ }^{210} \mathrm{Po}$ ingrowth from ${ }^{210} \mathrm{~Pb}$ in the sample. Activities at the time of sample collection were calculated from the two counts and the right decay corrections. Uncertainties were calculated by standard propagation of the \pm 1 sigma counting errors of samples and blanks. Apparent sedimentation rates were calculated using the CF-CS model (Constant Flux-Constant Sedimentation) of Anderson et al. (1987). In this model, the compaction effect is not considered, and apparent rates correspond to maximum values.

\subsection{Satellite data of sea surface chlorophyll $a$ concentration}

Monthly averaged images of surface chlorophyll $a$ (chl a) concentration from September 2007 to April 2008 (Fig. 2) and from September 2008 to April 2009 (Fig. 3), estimated with the Moderate Resolution Imaging Spectroradiometers (MODIS) Aqua $4 \mathrm{~km}$ instrument, were recovered from NASA's Giovanni portal (http://disc.sci.gsfc.nasa.gov/giovanni). Monthly fluctuations of spatially averaged chl a concentrations in a quadrilateral $\left(41^{\circ} 30^{\prime}-42^{\circ} 30^{\prime} \mathrm{N}, 4^{\circ}-5^{\circ} 30^{\prime} \mathrm{E}\right)$ encompassing the mooring array and covering roughly the deep convection region were also estimated for the September 2007 to April 2009 period (Fig. 8a). Monthly rather than weekly or daily composites were chosen to limit noise or gaps due to cloud cover.

\subsection{Integrated net heat fluxes}

Components (sensible, latent and radiative) of atmospheric heat fluxes were collected from ECMWF (European Centre for Medium-Range Weather Forecasts). The model is based on a $0.25^{\circ} \times 0.25^{\circ}$ lat/long grid and 3-h forecast intervals. We chose to extract data from the closest grid point $\left(42^{\circ} \mathrm{N}\right.$, $4.75^{\circ}$ E) to MF-LION location (Fig. 1).

\subsection{Side-scan sonar}

Side-scan sonar data was obtained onboard R/V Professor Logachev in August 2004 (Lastras et al., 2007), using a MAK-1M deep-towed platform. The MAK-1M consists of a $30 \mathrm{kHz}$ sidescan sonar that yields a total swath range of up to $2 \mathrm{~km}$ from a mean altitude of $100 \mathrm{mab}$, with a variable resolution of about 7 to $1 \mathrm{~m}$ across track and along track. The system was operated along the canyon floor of the Sète canyon distalmost reach and was used to characterize seafloor morphology near the mooring sites.

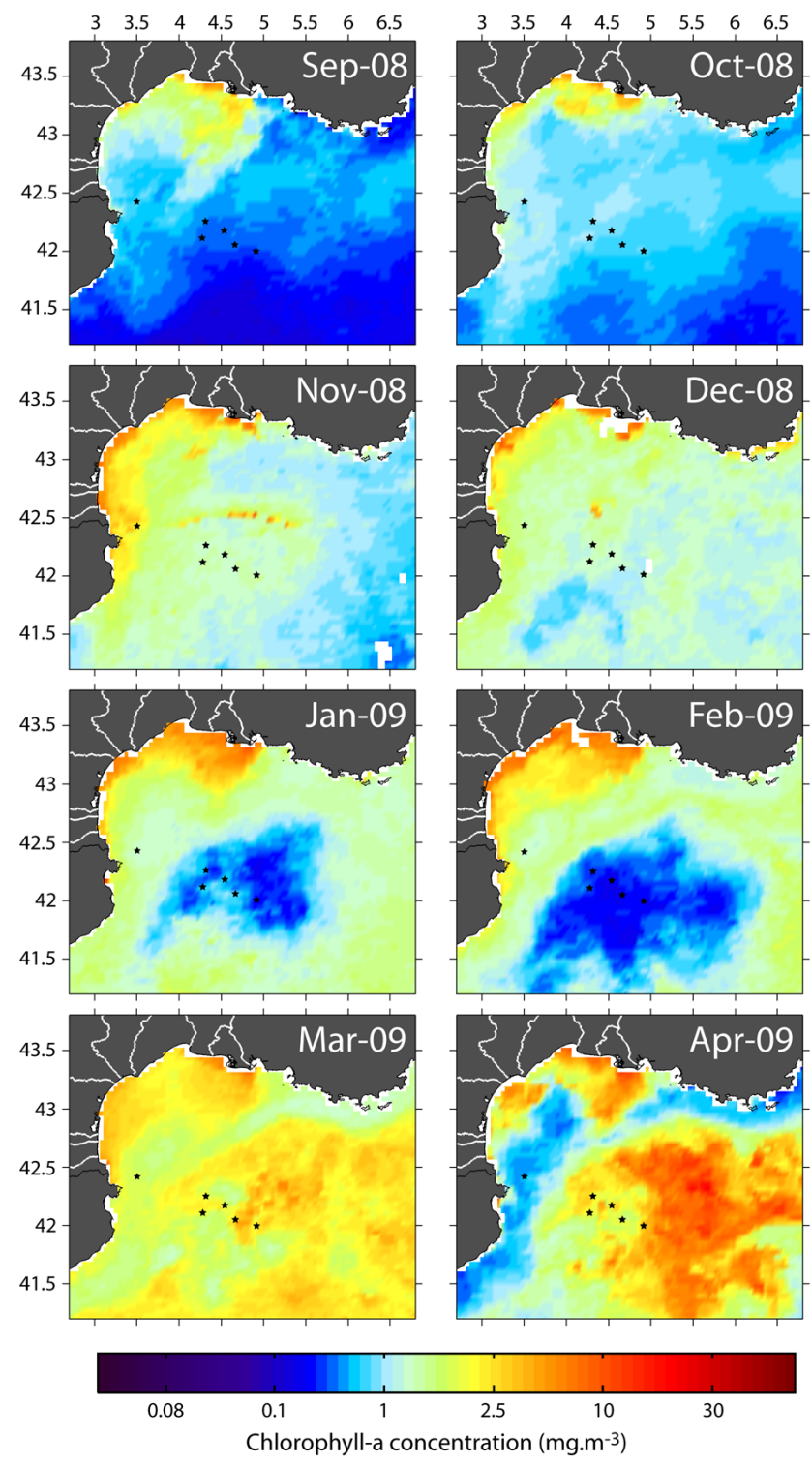

Fig. 3. Monthly averaged MODIS-Aqua $4 \mathrm{~km}$ surface chl $a$ images from September 2008 to April 2009. The black stars indicated the location of the mooring sites. Satellite data were downloaded from NASA's Giovanni portal (http://disc.sci.gsfc.nasa.gov/giovanni).

\section{Results}

\subsection{Spatial variability of $\operatorname{chl} a$ in the open-ocean convection zone}

Monthly-averaged sea surface chl $a$ concentrations from September 2007 to April 2008 (Fig. 2) and from September 2008 to April 2009 (Fig. 3) exhibited the typical seasonal variation of the surface primary production in the northwestern Mediterranean basin as described by D'Ortenzio and Ribera d'Alcalà (2009) with (i) low chl $a$ concentration and productivity at the end of summer because of the depletion of 

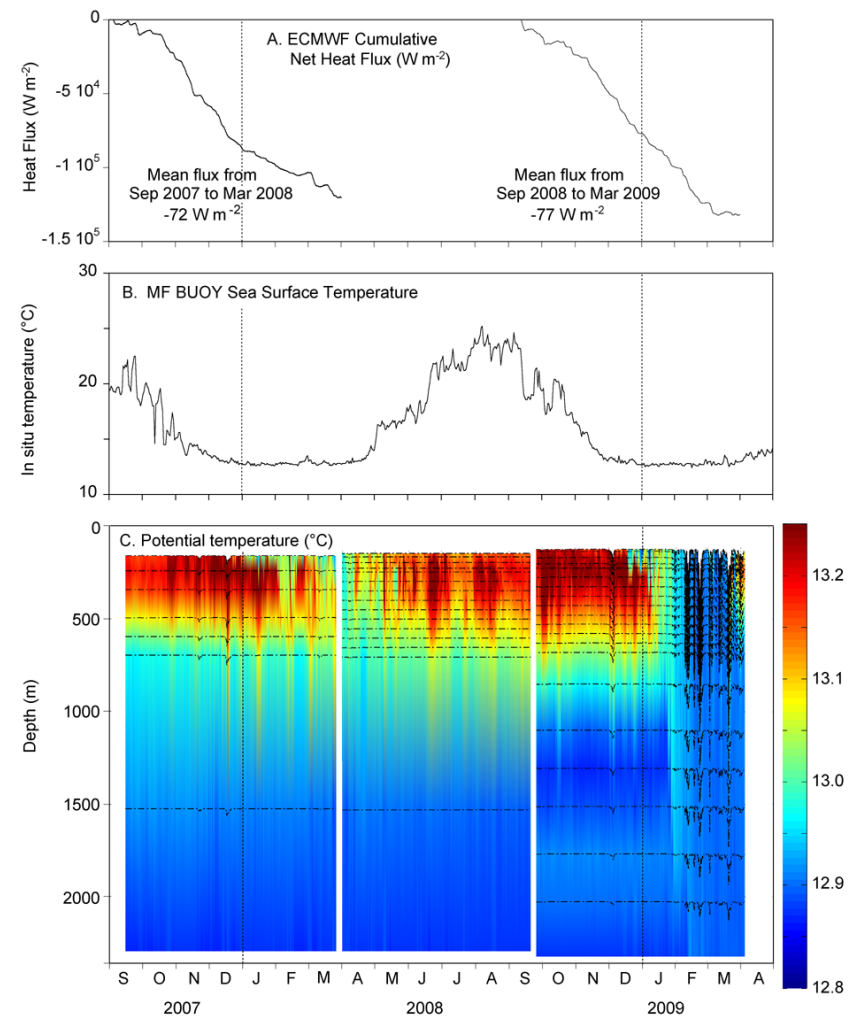

Fig. 4. Time series of (A) surface cumulative net heat losses, (B) sea surface temperature measured at the Météo-France buoy in the convection area, and $(\mathbf{C})$ vertical distribution of potential temperature at the SC2350 site from September 2007 to April 2009. Black dotted lines indicate the depth of the different temperature sensors. Note the deepening of the instruments during the winter 2008-2009 due to the strong currents.

nutrients in the surface layer, (ii) an increase of chl $a$ concentration during the fall planktonic bloom owing to erosion of the seasonal thermocline and, (iii) a minimum chl $a$ concentration and production during winter due to the intense vertical mixing, and (iv) a large increase in late winter/early spring associated with the large planktonic bloom that takes place when the restratification of the surface layer occurs and the surface layer has been enriched in nutrients from deeper waters.

As already shown by Morel and André (1991) and Santoleri et al. (2008), the location and extent of the OOC region in the Gulf of Lions was approximated for each winter from the patch of minimum chl $a$ concentrations characteristics of deep-water formation. During winter 2007-2008, only a small patch of low (minimum $0.5 \mathrm{mg} \mathrm{m}^{-3}$ ) chl $a$ concentration was visible in January, while during winter 2008-2009 a large patch of low chl $a$ lasted from December to February with minimum chl $a$ values of $0.2 \mathrm{mg} \mathrm{m}^{-3}$. The five deep mooring lines were located inside the OOC region, while the shallower mooring line in the Lacaze-Duthiers Canyon was outside.
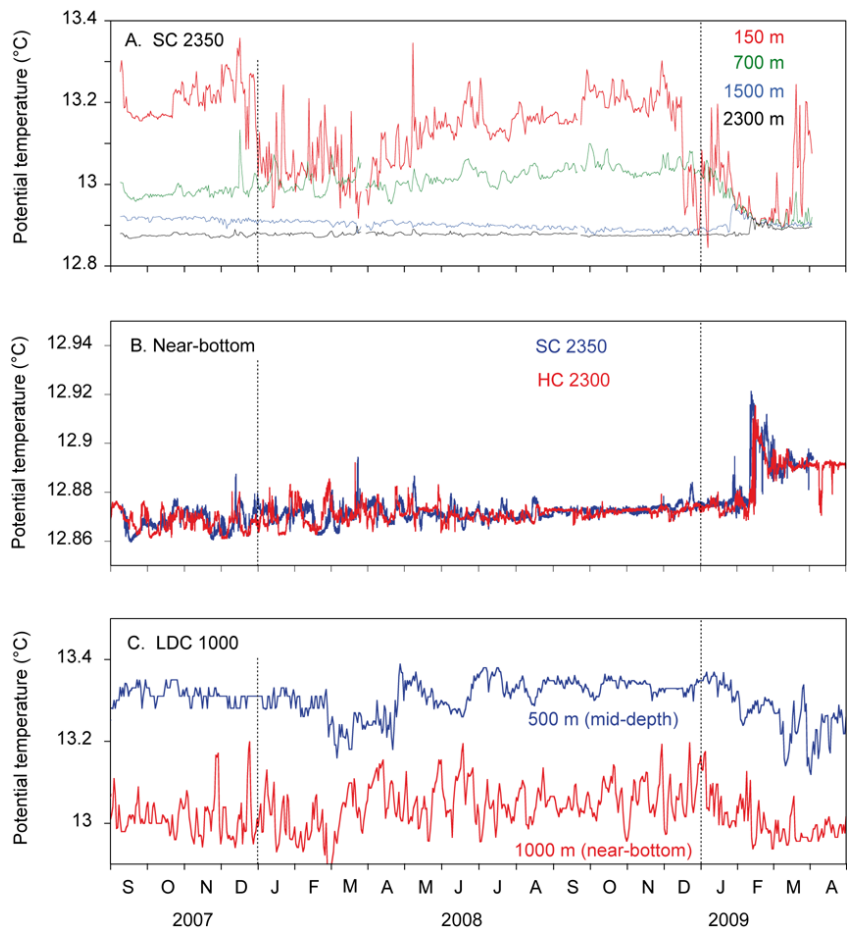

Fig. 5. Time series of (A) potential temperature at the LDC1000 site, (B) potential temperature at 150, 700, 1500 and $2300 \mathrm{~m}$ nominal depths at the SC2350 site, and (C) near-bottom potential temperature at SC2350 and HC2300 sites from September 2007 to April 2009.

\subsection{Temporal variability of integrated net heat fluxes and potential temperature}

The surface cumulated net heat flux for the convection region (Fig. 4a) indicated a progressive heat loss from the ocean to the atmosphere from September to March. Heat losses mostly resulted from the latent heat flux due to the wind-induced evaporation. The average loss for the September 2007 to March 2008 period was lower $\left(72 \mathrm{~W} \mathrm{~m}^{-2}\right)$ than for the September 2008 to March 2009 period $\left(77 \mathrm{~W} \mathrm{~m}^{-2}\right)$. The difference occurred mainly in wintertime.

The impact of the heat loss was clearly visible on the sea surface temperature (Fig. 4b), which decreased from $20-25^{\circ} \mathrm{C}$ in September to a minimum of about $13^{\circ} \mathrm{C}$ in late December (preconditioning phase). The effect on the water column (Fig. 4c) showed the gradual cooling and mixing of the intermediate water layer with the surface layer starting in December.

Minimum temperature of about $13^{\circ} \mathrm{C}$ was briefly reached in late March 2008, while temperature dropped to about $12.9^{\circ} \mathrm{C}$ between mid-February and mid-March 2009 . The observed mixed layer depth during the mixing phase in winter 2007-2008 was about 700-m depth, but reached the bottom (2350-m depth) during winter 2008-2009 (Fig. 5a). The arrival of newly-formed deep water at the bottom is shown 

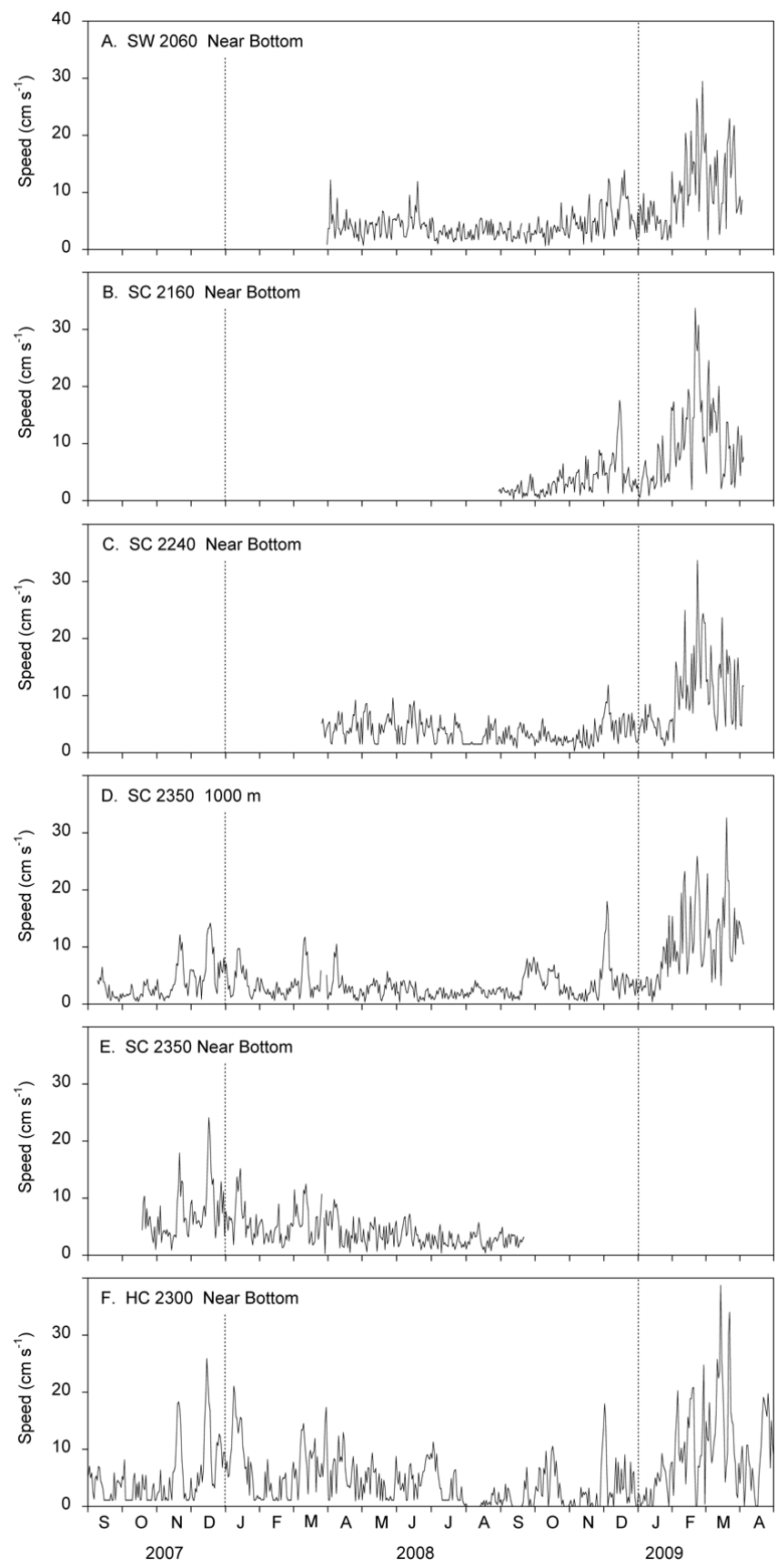

Fig. 6. Time series of current magnitude at few tens of meters above seabed at SW2060 (A), SC2160 (B), SC2240 (C), SC2350 (E) and HC2300 (F), and at mid-depth at SC2350 (D) from September 2007 to April 2009.

by the abrupt increase of near-bottom temperature of about $0.05^{\circ} \mathrm{C}$ in mid-February 2009 (Fig. 5b), followed by a gradual decrease linked to the continuation of the water column cooling by atmospheric forcing. A similar temperature increase was observed in mid-February at the other sites from the lower resolution current meter temperature sensor (data not shown). A rapid restratification of the upper water col-
Table 4. Statistics of near bottom hourly current speed measured at the HC2300 mooring for the winters 2007-2008 and 2008-2009.

\begin{tabular}{|c|c|c|}
\hline & $\begin{array}{c}\text { Winter } \\
2007-2008\end{array}$ & $\begin{array}{r}\text { Winter } \\
2008-2009\end{array}$ \\
\hline & $\begin{array}{r}1 \text { Feb } 2008 \text { to } \\
30 \text { Apr } 2008\end{array}$ & $\begin{array}{l}1 \text { Feb } 2009 \text { to } \\
30 \text { Apr } 2009\end{array}$ \\
\hline Number of measures & 1080 & 1068 \\
\hline Mean speed $\left(\mathrm{cm} \mathrm{s}^{-1}\right)$ & 5.9 & 11.2 \\
\hline Maximum speed $\left(\mathrm{cm} \mathrm{s}^{-1}\right)$ & 18.5 & 40.0 \\
\hline Standard deviation $\left(\mathrm{cm} \mathrm{s}^{-1}\right)$ & 3.9 & 7.8 \\
\hline$\% V<5 \mathrm{~cm} \mathrm{~s}^{-1}$ & 44.8 & 21.2 \\
\hline $5 \mathrm{~cm} \mathrm{~s}^{-1}<\% \mathrm{~V}<10 \mathrm{~cm} \mathrm{~s}^{-1}$ & 40.5 & 27.8 \\
\hline $10 \mathrm{~cm} \mathrm{~s}^{-1}<\% \mathrm{~V}<15 \mathrm{~cm} \mathrm{~s}^{-1}$ & 13.0 & 23.5 \\
\hline $15 \mathrm{~cm} \mathrm{~s}^{-1}<\% \mathrm{~V}<20 \mathrm{~cm} \mathrm{~s}^{-1}$ & 1.7 & 15.8 \\
\hline $20 \mathrm{~cm} \mathrm{~s}^{-1}<\% \mathrm{~V}<25 \mathrm{~cm} \mathrm{~s}^{-1}$ & 0.0 & 5.3 \\
\hline $25 \mathrm{~cm} \mathrm{~s}^{-1}<\% \mathrm{~V}<30 \mathrm{~cm} \mathrm{~s}^{-1}$ & 0.0 & 3.8 \\
\hline$\% V>30 \mathrm{~cm} \mathrm{~s}^{-1}$ & 0.0 & 2.6 \\
\hline
\end{tabular}

umn started in late-March for both years, marking the beginning of the sinking and spreading phase (Fig. 4c).

On the slope site (LDC1000), the temperature records at 500 and 1000-m depth showed a slight cooling of about $0.1^{\circ} \mathrm{C}$ during wintertime, in particular at mid-depth (Fig. 5c). The absence of significant $\left(>1{ }^{\circ} \mathrm{C}\right)$ near-bottom temperature drop at 1000-m depth, characteristics of deep cascading of dense shelf water (Heussner et al., 2006; Palanques et al., 2012), indicated that water exported from the shelf was not dense enough to reach the rise and remained on the upper slope.

\subsection{Variability of currents}

The magnitude of near-bottom currents at the different sites and mid-depth currents showed a significant coherency (Fig. 6). Two distinct periods may be defined, i.e., the late spring-early autumn (May-October) period with low values (average and maximum speeds of about 3 and $11 \mathrm{~cm} \mathrm{~s}^{-1}$, respectively) that contrasted with the late fall-early spring (November-April) period, with higher values (average and maximum speeds of about 6.7 and $40 \mathrm{~cm} \mathrm{~s}^{-1}$, respectively).

Important differences appeared for the two late fall-early spring periods (Fig. 6). During November 2007-April 2008, few significant current bursts were recorded close to the bottom at SC2350 and HC2300 and at mid-water depth at SC2350. During November 2008-April 2009, a first current burst took place in November 2008 and strong currents persisted in February and March 2009 at all sites. Average current velocity during that latter period was about $13 \mathrm{~cm} \mathrm{~s}^{-1}$. Comparison of near-bottom current statistics at HC2300 (Table 4) for the February-April periods indicated that (i) average currents were stronger during winter $2009\left(11.2 \mathrm{~cm} \mathrm{~s}^{-1}\right)$ than during winter $2008\left(5.9 \mathrm{~cm} \mathrm{~s}^{-1}\right)$, and (ii) the occurrence 

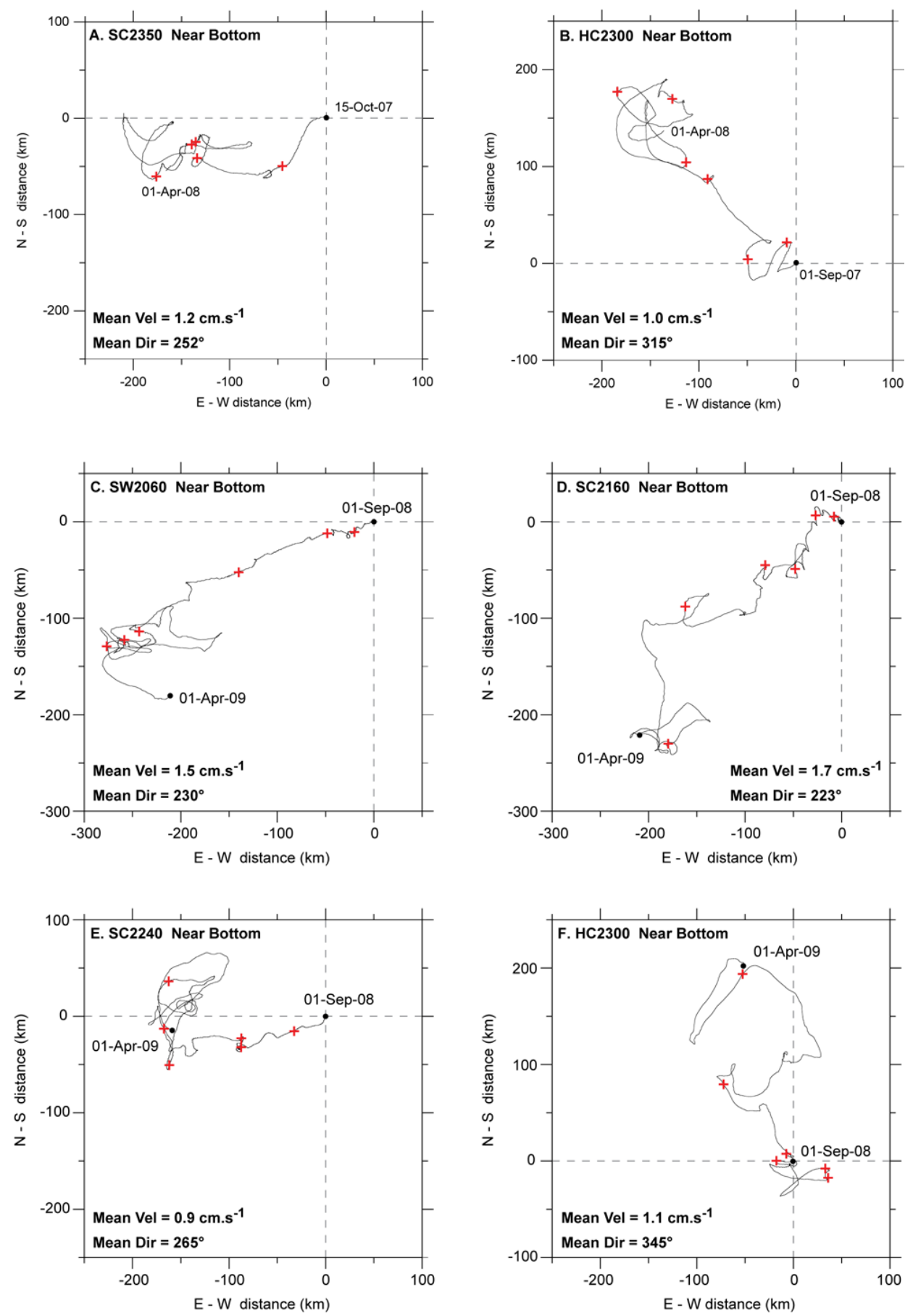

Fig. 7. Progressive vector diagrams of the near-bottom currents from September 2007 to April 2008 at SC2350 (A) and HC2300 (B), and from September 2008 to April 2009 at SW2060 (C), SC2160 (D), SC2240 (E), and HC2300 (F). Mean velocity and direction of the currents for the selected periods are indicated. Crosses represent time periods of one month.

of high current speeds $\left(>25 \mathrm{~cm} \mathrm{~s}^{-1}\right.$ ) occurred only in winter 2009 for $11.7 \%$ of the time.

Progressive vector diagrams of the near-bottom current during September 2008-April 2009 revealed the variability of the current direction in the study area (Fig. 7). Superim- posed to the slow mean currents, large fluctuations of several days to weeks, distinctive of eddy-like flow patterns, dominated especially during winter. Faint near-inertial motions (period around $17.5 \mathrm{~h}$ ) also existed. 
Table 5. Main statistics (maximum, minimum and mean) of mass flux, POC content and POC flux in SW2060, SC2160, SC2240 nearbottom traps and in SC2350 mid-depth and near-bottom sediment traps. Mean flux has been calculated as time-weighted average (TWA). Mean content has been calculated as flux and time weighted average (FTWA).

\begin{tabular}{llrrr|rr}
\hline Site & & SW2060 & SC2160 & SC2240 & \multicolumn{2}{c}{ SC2350 “Lion” } \\
\hline Trap depth & & Near-bottom & Near-bottom & Near-bottom & Mid-depth & Near-bottom \\
\hline Mass flux & Max & 5190 & 2204 & 3970 & 818 & 7180 \\
$\left(\mathrm{mg} \mathrm{m}^{-2} \mathrm{~d}^{-1}\right)$ & Min & 5 & 5 & 9 & 5 & 5 \\
& TWA & 487 & 367 & 366 & 91 & 401 \\
\hline POC content & Max & 5.8 & 6.4 & 7.3 & 16.5 & 10.2 \\
$(\%$ d. w. $)$ & Min & 0.9 & 1.2 & 1 & 1.9 & 0.8 \\
& FTWA & 1.7 & 2.2 & 2.1 & 5.5 & 1.7 \\
\hline POC flux & Max & 3.89 & 3.97 & 4.44 & 3.95 & 4.90 \\
(mMol C $\left.{ }^{-2} \mathrm{~d}^{-1}\right)$ & Min & 0.03 & 0.02 & 0.02 & 0.06 & 0.05 \\
& TWA & 0.76 & 0.68 & 0.64 & 0.43 & 0.61 \\
\hline
\end{tabular}

\subsection{Variability of chl $a$, mass flux, and particulate organic carbon content and flux in the convection region}

The time series of monthly averaged surface chl $a$ concentration in the convection region (Fig. 8a) showed a typical annual signal with summer minimum and spring maximum. In summer chl $a$ concentration ranged between 0.1 and $0.2 \mathrm{mg} \mathrm{m}^{-3}$. It increased in fall, especially in November 2008 (up to $0.4 \mathrm{mg} \mathrm{m}^{-3}$ ), then decreased in winter (down to $\left.0.2 \mathrm{mg} \mathrm{m}^{-3}\right)$, and increased again in spring to reach maximum values $\left(0.8-1.4 \mathrm{mg} \mathrm{m}^{-3}\right)$ during the planktonic bloom. In 2008, chl $a$ increased steadily from January to reach highest values in March and April (1.2 and $1.0 \mathrm{mg} \mathrm{m}^{-3}$, respectively). In contrast, in 2009, chl $a$ sharply increased in February to reach its maximum $\left(1.4 \mathrm{mg} \mathrm{m}^{-3}\right)$ in April.

The main statistics of total mass flux (TMF) and particulate organic carbon (POC) content for all traps are given in Table 5. Time-weighted average of near-bottom TMF for the entire sampling period varied within a narrow range (360-477 $\mathrm{mg} \mathrm{m}^{-2} \mathrm{~d}^{-1}$ ), while the mid-depth time-weighted average TMF was much lower $\left(90 \mathrm{mg} \mathrm{m}^{-2} \mathrm{~d}^{-1}\right)$. Likewise, the flux and time-weighted average POC content in nearbottom traps ranged between 1.7 and $2.2 \%$, whereas the flux and time-weighted average POC content at mid-depth was more than twice as high $(5.5 \%)$.

Total mass fluxes and POC content at the different sites showed rather similar temporal variations (Fig. 8b-f). Minimum TMF (5-9 $\mathrm{mg} \mathrm{m}^{-2} \mathrm{~d}^{-1}$ ) were recorded in summerfall and were associated with high POC contents. Maximum POC contents were observed in November 2008 with values of 5.8 and $7.7 \%$ near the bottom and increasing with water depth, and $16.5 \%$ at mid-depth. Maximum TMF were recorded near the bottom and at mid-depth in AprilMay 2008, and uniquely near the bottom in FebruaryMarch 2009. In April-May 2008, high TMF were associated with high POC contents (4.9-5.8\%), resulting in high POC fluxes (3.2-4.5 $\mathrm{mMol} \mathrm{C} \mathrm{m}^{-2} \mathrm{~d}^{-1}$ ). In February-March 2009, near-bottom maximum TMF (2204-7180 $\mathrm{mg} \mathrm{m}^{-2} \mathrm{~d}^{-1}$ ) were one order of magnitude larger than the average flux, but were associated with the minimum POC contents (0.8-1.2\%), producing nonetheless significant POC fluxes (1.3-4.9 $\left.\mathrm{mMol} \mathrm{C} \mathrm{m}^{-2} \mathrm{~d}^{-1}\right)$. At the mid-depth TMF (84$\left.135 \mathrm{mg} \mathrm{m}^{-2} \mathrm{~d}^{-1}\right)$ as well as POC content (1.9-3.3\%) and flux $\left(0.16-0.24 \mathrm{mMol} \mathrm{C} \mathrm{m}^{-2} \mathrm{~d}^{-1}\right)$ were low. The continuation of the TMF pulse in late March-early April 2009, visible at the SC2160 and SC2240 sites (Fig. 7c-d), was associated with higher POC content (1.7-2.2\%), and POC flux at both sites was about $2-3 \mathrm{mMol} \mathrm{C} \mathrm{m}^{-2} \mathrm{~d}^{-1}$.

Comparison of near-bottom TMF at SC2350 for the winter period (December-March) indicated that the maximum TMF $\left(7180 \mathrm{mg} \mathrm{m}^{-2} \mathrm{~d}^{-1}\right)$ recorded in winter 2008-2009 was about two orders of magnitude higher than the maximum TMF $\left(169 \mathrm{mg} \mathrm{m}^{-2} \mathrm{~d}^{-1}\right)$ recorded in winter 2007-2008. At the same time the minimum POC content $(0.8 \%)$ in winter 2008-2009 was three times lower than the POC content $(2.8 \%)$ recorded in winter 2007-2008. These results at the near-bottom trap contrast with those at the upper trap that do not exhibit such large fluctuations between the two winters.

\subsection{Change of the bottom nepheloid layer structure}

The CTD cast performed next to the SC2350 site in March 2008 (Fig. 9a and c) revealed the vertical distribution of the major water masses present in the deep basin. A bottom nepheloid layer about 600-m thick (from the clear water minimum at $1800-\mathrm{m}$ depth to the bottom at $2350-\mathrm{m}$ depth) is primarily associated with the bottom water layer. A second CTD cast performed in May 2009 (Fig. 9b and d) revealed the appearance of a new bottom water mass with a warmer, saltier, and denser signature and high turbidity values. This new water mass laid below the existing bottom and 

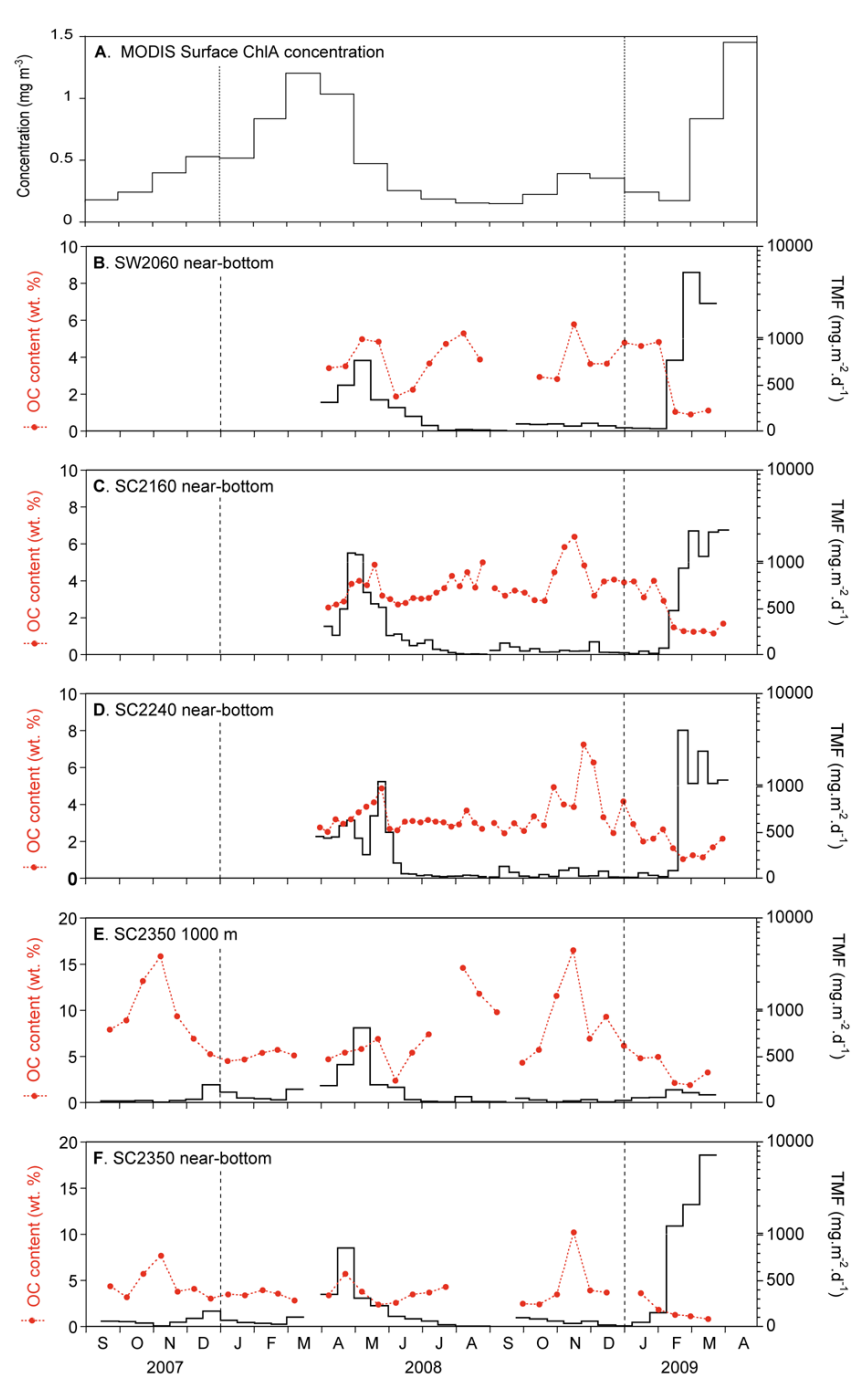

Fig. 8. Time series of monthly averaged sea surface chl $a$ concentration (in $\mathrm{mg} \mathrm{m}^{-3}$ ) in the OOC region (A), total mass fluxes (TMF, in $\mathrm{mg} \mathrm{m}^{-2} \mathrm{~d}^{-1}$ ) and particulate organic carbon (POC contents, in $\%$ of dry weight) at few tens of meters above seabed for SW2060 (B), SC2160 (C), SC2240 (D), and SC2350 (F), and at mid-depth for SC2350 (E) from September 2007 to April 2009.

deep water masses, and the resulting distribution produced a thicker bottom turbid layer that extend more than 1000 mab.

\subsection{Seabed characteristics}

Surface sediment characteristics at different sites are listed in Table 3. Sediment accumulation rates ranged between 0.07 and $0.22 \mathrm{~cm} \mathrm{yr}^{-1}$, and increased together with the clay content (from 15.8 to $26.3 \%$ ). These values are in agreement with other studies previously conducted in the deep basin of the Gulf of Lions (Miralles et al., 2005 and references therein) and in the Ligurian Sea (Martín et al., 2009; Heimbürger et al., 2012). Despite differences in sediment grain size and sedimentation rates, POC content was approximately the same at all sites (around $0.6 \%$ ).

Seabed morphology across the sediment wave field and along the distal reach of the Sète Canyon, where the mooring sites are located, is presented in Fig. 10. Furrows (Fig. 10b) are observed close to the SC2160 mooring line while crescent scours (Fig. 10c) and scours (Fig. 10d) are observed close to SC2240 and SC2350 mooring sites, respectively.

\section{Discussion}

Measurements obtained between September 2007 and April 2009 in the convection zone of the Gulf of Lions allow observing two contrasting winters. Winter 2007-2008 is characterized by a mild convection with a mixed layer depth limited to 1000-m depth, low current speeds and low particle fluxes in the water column and near the bottom. In contrast, winter 2008-2009 is characterized by a deep convection, with a mixed layer depth reaching to the bottom (2350$\mathrm{m}$ depth), stronger current speeds in the water column and near the bottom, and significant particle flux near the bottom. The extent of the convection zone, characterized by the minimum concentration of surface chl $a$, is smaller in winter 2007-2008 than in winter 2008-2009. The difference in the intensity of convection between the two winters primarily results from larger net heat losses during fall/winter 2008-2009 compared to fall/winter 2007-2008. At first, we consider the seasonal variability of currents and particle fluxes and interpret them in light of previous observations gathered in the northwestern Mediterranean Sea. Second, we will discuss the impact of the interannual variability of convection events and interactions with dense shelf water cascading on deep particle fluxes and the sustainment of a bottom turbid layer in the deep basin. Finally, we will discuss the effect of convection events on sedimentary substrates and deep-sea ecosystems.

\subsection{Comparison with other Northwestern Mediterranean oceanic sites}

Deep particle fluxes have been measured only once in the Gulf of Lions region, at the Eflubio site $\left(41^{\circ} 48^{\prime} \mathrm{N}-5^{\circ} 12^{\prime} \mathrm{E}\right.$, at $2350-\mathrm{m}$ depth). Total mass flux measured from November 2003 to March 2005 varied within four orders of magnitude with a marked seasonal variability (Palanques et al., 2009). Total mass flux was generally low, between 20 and $100 \mathrm{mg} \mathrm{m}^{-2} \mathrm{~d}^{-1}$, except during winter reaching 2820 and $16270 \mathrm{mg} \mathrm{m}^{-2} \mathrm{~d}^{-1}$ in 2004 and 2005 , respectively. The authors associated the origin of the large TMF in winter 2004-2005 primarily to exceptionally intense and persistent DSWC. However, it was also observed close to the bottom exceptionally strong current velocities (up to $47 \mathrm{~cm} \mathrm{~s}^{-1}$ ) and a temperature increase (approx. $0.1{ }^{\circ} \mathrm{C}$ ). Given that OOC was exceptionally strong during the winter 2004-2005 (Puig et 

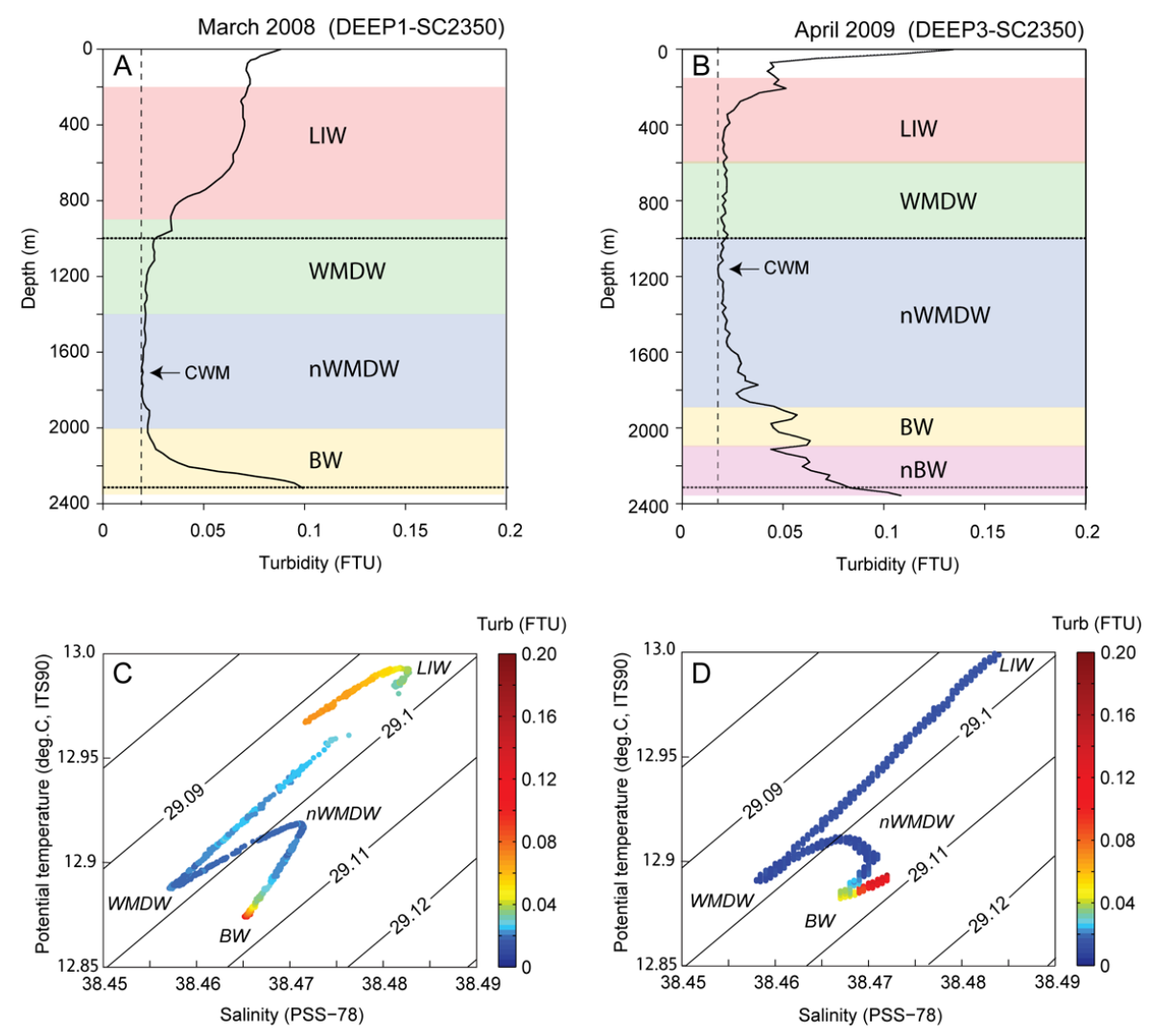

Fig. 9. Turbidity profiles from CTD casts performed in the vicinity of the SC2350 site in March 2008 (A) and May 2009 (B). The clear water minimum (CWM) that defines the upper limit of the bottom nepheloid layer is around 1600-1800-m depth in 2008 and $1200-\mathrm{m}$ depth in 2009. The major water masses LIW (Levantine Intermediate Water), WMDW (old western Mediterranean Deep Water), nWMDW (new western Mediterranean deep Water), BW (bottom water) are indicated. The horizontal dotted lines indicated the depth of the sediment traps on the SC2350 mooring line. Associated potential temperature-salinity diagrams in March 2008 (C) and May 2009 (D) where in color indicated the turbidity (in FTU).

al., 2012) the large TMF is rather originating from both deep DSWC and OOC events than from deep DSWC event only.

Deep particle fluxes are also monitored at two other sites in the northwestern Mediterranean Sea, east of the Gulf of Lions: the ANTARES Site $\left(42^{\circ} 50^{\prime} \mathrm{N}-6^{\circ} 10^{\prime} \mathrm{E}\right.$ at $2400-\mathrm{m}$ depth) and in the Ligurian Sea at the DYFAMED site $\left(43^{\circ} 25^{\prime} \mathrm{N}-\right.$ $7^{\circ} 52^{\prime} \mathrm{E}$ at 2330 -m depth). At the ANTARES site, TMF measured between July 1997 and January 1998 varied between $19 \mathrm{mg} \mathrm{m}^{-2} \mathrm{~d}^{-1}$ (end of August) and $352 \mathrm{mg} \mathrm{m}^{-2} \mathrm{~d}^{-1}$ (midOctober and mid-November) with a clear seasonal cutoff between the summer and fall periods (Amram et al., 2003). In the absence of any peculiar convection event and low current velocities $\left(<15 \mathrm{~cm} \mathrm{~s}^{-1}\right)$ these TMF match with those observed during the same seasons in the Gulf of Lions (5$169 \mathrm{mg} \mathrm{m}^{-2} \mathrm{~d}^{-1}$ ). More recently, Al Ali et al. (2010) reported for the April to early-September 2005 period an average TMF of $77.9 \mathrm{mg} \mathrm{m}^{-2} \mathrm{~d}^{-1}$ and an average POC content of $5.5 \%$ at $2235-\mathrm{m}$ depth (150 mab). In early April 2005, TMF reached a maximum of $1331 \mathrm{mg} \mathrm{m}^{-2} \mathrm{~d}^{-1}$, and POC content dropped to $1.5 \%$. Although no current meter data were presented, the authors suggested that the high flux and low POC content may be due to (1) sediment resuspension by deep water formation and/or (2) large particle export flux by intense DSWC event of winter 2004-2005 (Canals et al., 2006).

Subsurface (200-m depth) and mid-depth (1000-m depth) particle fluxes are also monitored at DYFAMED site in the nearby Ligurian Sea (Miquel et al., 2011). Seasonal patterns of TMF in the Gulf of Lions, with highest export flux during winter-spring and lowest export flux during summer-fall, are similar to those observed at the DYFAMED site. The average TMF (90 $\mathrm{mg} \mathrm{m}^{-2} \mathrm{~d}^{-1}$ ) measured at $1000-\mathrm{m}$ depth in the Gulf of Lions is similar to that observed at the DYFAMED site from 1988 to 2005 at 1000 -m depth $\left(87.4 \mathrm{mg} \mathrm{m}^{-2} \mathrm{~d}^{-1}\right)$. The temporary presence of a near-bottom sediment trap (20 mab) during 2005-2006 allowed Martín et al. (2010) to describe the impact of the 2006 open-ocean deep convection event on particle fluxes. They reported maximum near-bottom fluxes of $9188 \mathrm{mg} \mathrm{m}^{-2} \mathrm{~d}^{-1}$, associated with low POC contents $(0.9-1.5 \%)$ and large current velocities (up to $38.6 \mathrm{~cm} \mathrm{~s}^{-1}$ ), which are comparable to the values observed in the Gulf of Lions during the winter 2008-2009 with near-bottom fluxes 

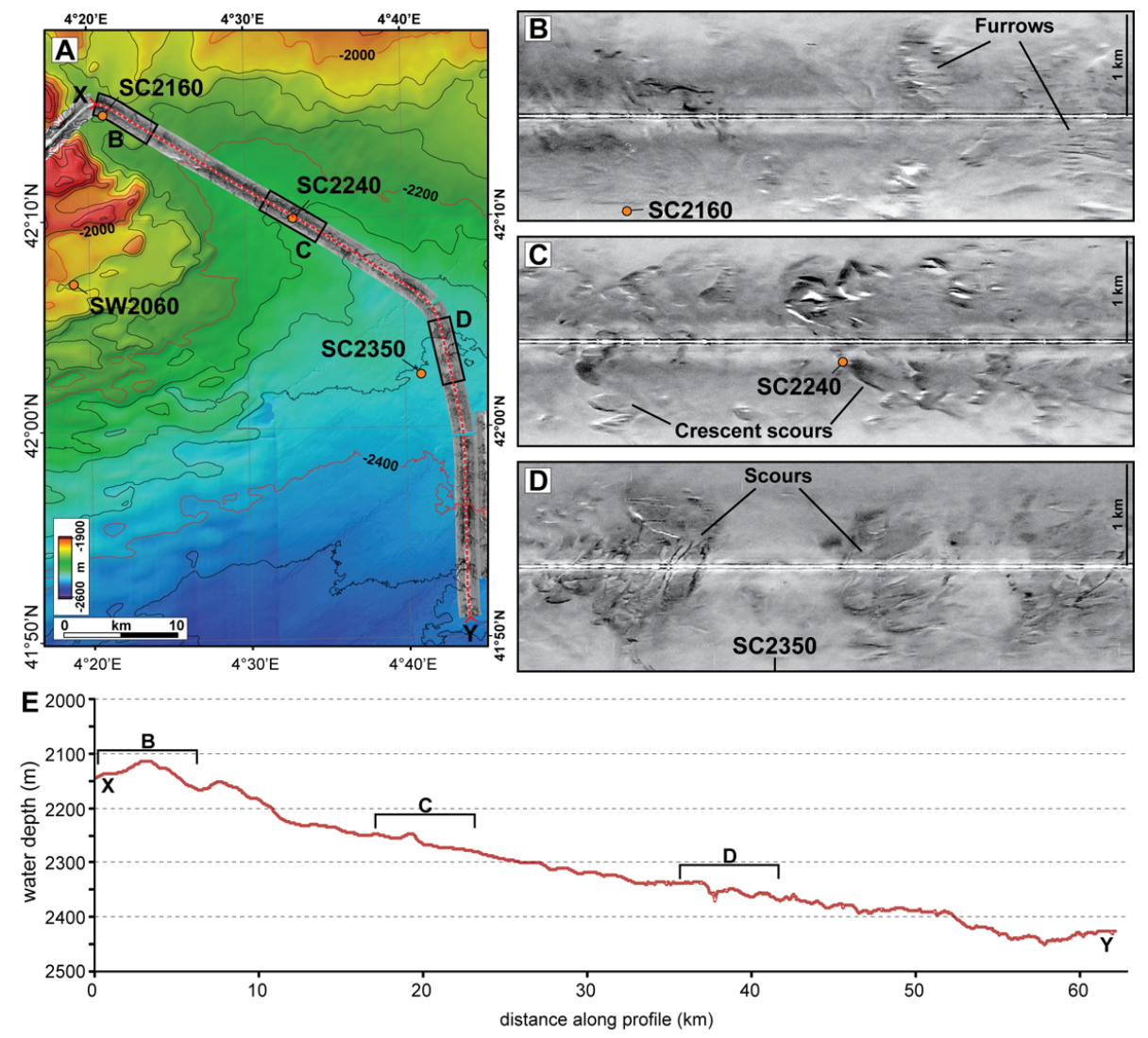

Fig. 10. Seabed morphology across the sediment wave field and along the Sète Canyon distalmost reach, where the mooring sites are located (see Fig. 1). (A) Multibeam-derived bathymetry contour map, contours every $100 \mathrm{~m}$. Transect shown as dotted red line from $X$ to $Y$. Note location of figures (B), (C) and (D) along the section. (B), (C) and (D) MAK-1M side-scan sonographs and (E) Bathymetric section along $(X-Y)$. Sonographs are presented in inverse grey-scale (insonified areas are dark grey and black, whereas shadows are in white).

of $5190-7180 \mathrm{mg} \mathrm{m}^{-2} \mathrm{~d}^{-1}$ and POC contents between 0.9 and $1.2 \%$.

Our observations of near-bottom and mid-depth particle fluxes are comparable to the existing observations, in terms of seasonal variability and range both in the Gulf of Lions and in the nearby Ligurian Sea. Moreover, the observation of the intense convective winter of 2004-2005 in the Gulf of Lions (Palanques et al., 2009), and the one of 2005-2006 in the Ligurian Sea (Martín et al., 2010) allow a comparison of the impact of OOC on deep particle fluxes.

\subsection{Variability of open-ocean convection and its impacts on deep particle fluxes}

The different OOC intensities observed for both winters are typical for the interannual variability already observed in the region (Mertens and Schott, 1998; Bethoux et al., 2002; Herrmann et al., 2009). According to these authors, 18 yearly events of deep OOC, responsible for the ventilation of deep waters, occurred during the 1971-2008 period. Thus, our observations present a unique opportunity to compare two con- trasted winters and to assess the impact of deep OOC on deep particle fluxes.

Compared to the mild convection in winter 2007-2008, the larger intensity of the convection during the winter 2008-2009 results in lower surface phytoplankton concentration in the water column in the convective area, a significant increase of near-bottom TMF, and an overall decrease in POC content (Figs. 2, 3, and 8a). Two potential mechanisms are considered to explain these differences: the variability of the exported particle fluxes from the surface layer, and resuspension of seabed.

Causal relationships between hydrological processes in, and around the convection region and the planktonic production have been shown based on modeling approaches (Lévy et al., 2000; Auger, 2011). These studies emphasize the major effect of vertical mixing and mesoscale activity on primary production and POC export. They showed that, for deep winter mixing biomass in the convective area is strongly diluted because of the limitation of photosynthesis by the reduced exposure time of phytoplankton to light, and mechanical decoupling of prey and predators. The majority of phytoplankton production is obtained at the rim of the convective area, 
where the mixed layer is shallowest. Auger (2011) further indicates that POC export by turbulence and advection culminate during the vertical mixing period, while POC export by sedimentation, which is directly related to the organic matter content, culminates during the spring phytoplankton bloom following the peak of vertical mixing. Hence, one might infer that the mild convection (reaching 700-m depth) in late March 2008 does not to affect mid-depth and near-bottom fluxes and POC content (Fig. 8e and f). Conversely, the low biomass and primary production during the intense vertical mixing in late February 2009 likely contribute to the reduction of POC content observed at mid-depth and near the bottom (Fig. 8). After the mixing period, the increased TMF and POC content observed in April-May 2008, as well as the slight increase of POC content observed in late Marchearly April 2009 are probably caused by the settling and advection of organic matter produced in the surface layer during the late winter-early spring blooms. It is noteworthy that highest POC contents at 1000-m depth and near the bottom, which likely relate to rapid settling of organic matter produced during the fall bloom, are observed in both years (2008 and 2009) in October-November.

The potential impact of deep OOC on sediment remobilization at 2330-m depth has been shown by Martín et al. (2010) in the nearby Ligurian Sea. The authors showed that, during the winter 2005-2006 deep OOC event, nearbottom currents were markedly intensified (up to $39 \mathrm{~cm} \mathrm{~s}^{-1}$ ), and that near-bottom particle fluxes increased at the same time by two orders of magnitude. In the Gulf of Lions, TMF at mid-depth and near the bottom for the SC2350 site show very similar variations, except during the winter 2008-2009 when near-bottom TMF exceeded mid-depth fluxes by two orders of magnitude (Fig. 8e and f). This abrupt increase of near-bottom TMF takes place at all sites and comes at a time when bottom currents significantly increase (average velocity $\sim 13 \mathrm{~cm} \mathrm{~s}^{-1}$ and peaks $>25 \mathrm{~cm} \mathrm{~s}^{-1}$, Fig. 6). Such current velocity peaks, which exceeded the critical threshold for fine silts $(<16 \mu \mathrm{m})$ as calculated from the SEDTRANS model ( $\mathrm{Li}$ and Amos, 2001), are probably large enough to resuspend the superficial fine sediments of the deep basin. The strong vertical mixing (Fig. 5a and b) and significant mesoscale activity of horizontal currents (Fig. 7) also allow the dispersal of the suspended sediment several hundred meters above the seabed (Fig. 9b) and over a widespread area. Moreover, the contribution of sedimentary material poor in POC along with the dilution of the biomass by vertical mixing result in low POC content in near-bottom sediment trap samples. Thus, in the absence of noticeable lateral input from the nearby margin by DSWC that remains mild during the period of study (Fig. 5c), most material collected by the near-bottom sediment traps in February-March 2009 is probably composed of sediment which has been resuspended from the deep OOC area. This result complements the conclusions of Palanques et al. (2009) who described a similar event in the deep basin of the Gulf of Lions during the 2005 exceptional convective event. The authors relate the large increase of near-bottom flux, which peaked at $16270 \mathrm{mg} \mathrm{m}^{-2} \mathrm{~d}^{-1}$, primarily to lateral advection of dense turbid water cascading from the western shelf of the Gulf of Lions. They considered that potential contribution of deep sediment resuspension by strong currents (between 20 and $47 \mathrm{~cm} \mathrm{~s}^{-1}$ ) could have been also possible, but less intense due to the position of the trap farther from the seabed (250 mab). Given the absence of turbid bottom layer in the years preceding this event (Puig et al., 2012) the availability of easily resuspendable sediment may have been reduced. However, other studies conducted in 2005-2006 on the western slope of the Gulf of Lions showed that the maximum near-bottom (30 mab) TMF collected at 1900-m depth during the intense 2006 DSWC event range between 3200 and $5700 \mathrm{mg} \mathrm{m}^{-2} \mathrm{~d}^{-1}$ and were about one order of magnitude lower than the near-bottom TMF at 1000-m depth on the upper slope and canyons that range between 34100 and $90080 \mathrm{mg} \mathrm{m}^{-2} \mathrm{~d}^{-1}$ (Pasqual et al., 2010). The latter work concluded to a significant decrease in the transport capacity of the dense shelf-water plume along its down-canyon and down-slope propagation. These observations suggest that the particle load transported during this deep DSWC event would have been even more diluted when reaching the deeper OOC area. Fluxes measured at 1900-m depth during the winter 2005-2006, however, are four times lower than those measured at 2400-m depth during the winter 2004-2005, while these two years were characterized by intense DSWC and OOC events. The large discrepancy suggests an additional source of particulate matter in the deep basin, such as sediment resuspension by open-ocean deep convection, must be considered to explain the significant increase in particulate fluxes during winter 2004-2005.

We propose here three different scenarios to better describe the plausible origin of the near-bottom TMF in the deep basin of the Gulf of Lions during winter: (1) moderate TMF $\left(<1000 \mathrm{mg} \mathrm{m}^{-2} \mathrm{~d}^{-1}\right)$ from a dominant biological source resulting from the surface production export during the winters of shallow OOC, as in 2008; (2) large TMF (up to $10000 \mathrm{mg} \mathrm{m}^{-2} \mathrm{~d}^{-1}$ ) from a dominant sedimentary source due to the remobilization of surface sediment of the deep basin during winters with both deep OOC and shallow DSWC, as in 2009; and (3) extreme TMF $\left(>10000 \mathrm{mg} \mathrm{m}^{-2} \mathrm{~d}^{-1}\right.$ ) from a dominant sedimentary source due to the remobilization of surface sediments from the shelf and slope and mainly from the deep basin during winters with both deep OOC and deep DSWC, as in 2005.

In a compilation of numerous CTD casts conducted in the western Mediterranean from 1998 to 2011, Puig et al. (2012) show that the large bottom nepheloid layer observed during our study period (2007-2009) has been formed during the winter 2004-2005 and is primarily associated with bottom water arising from the cascading of very dense and turbid water. The evolution of this bottom nepheloid layer during the following years shows a progressive fading until 2009 when it grows again. In view of our results, we can ascribe 
the replenishment of the bottom nepheloid layer to the remobilization of basin sediment by deep OOC.

\subsection{Impacts of open-ocean deep convection events on seabed and benthic ecosystems}

While deep OOC is very infrequent in the Ligurian Sea (one single event for the 1995-2007 period as observed by Marty and Chiavérini, 2010) and thus rarely affects the deep sediment (Martin et al., 2010). On the contrary, the recurrent deep OOC events in the Gulf of Lions continuously rework bottom sediments and a long-term alteration of the sediment might be expected.

Various geophysical and acoustic imagery investigations performed on the slope and rise of the Gulf of Lions (Kenyon et al., 1995; Droz et al., 2001; Bonnel et al., 2005; Jallet and Giresse, 2005; Lastras et al., 2007) revealed erosional features generated by bedload transport processes (sediment waves, crescent scours, furrows, grooves, and mega-ripples). Examples of such bedforms close to the mooring sites are given in Fig. 10. The question of the origin of these erosional bedforms has been little investigated. On the slope and particularly in the Cap de Creus Canyon, Canals et al. (2006) and Puig et al. (2008) show that the rapid downward bottom currents and sand transport associated with DSWC events are prone to generate distinctive erosional bedforms, such as megascale longitudinal furrows, which extend also over the middle canyon down to $1400-\mathrm{m}$ depth. On the rise, the flattening of the seabed and the decreasing of density contrast of the dense water plume with the ambient water slow the cascading currents and its erosive potential (Palanques et al., 2012).

At the base of slope, the observed strong bottom currents in the present and previous studies (Millot and Monaco, 1984; Schott et al., 1996; Palanques et al., 2009) mostly relate to the deep OOC events. The periodical winnowing of surface sediments by these currents is thus thought to be responsible of the low sedimentation rates (Table 3 ). The observed giant erosional bedforms of the seabed (Fig. 10) form under unidirectional strong bottom currents that cannot be generated by deep OOC events, characterized by changing directions (Fig. 7). Depending on their orientation and shape they are interpreted (1) as formed by recent bottom current from the Cap de Creus and Sète Canyon, possibly triggered after DSWC events (Lastras et al. 2007), (2) as relict forms related to turbiditic current spillover from the adjacent PetitRhone turbiditic channel (Kenyon et al., 1995; Bonnel et al., 2005; Wynn et al., 2005). It has been pointed out that the floor of the giant scours is devoid of Holocene deposits, while a Holocene drape is well developed on the adjacent seabed (Fig. 10 in Dennielou et al., 2009). This can be interpreted as a possible imprint of the interaction of the deep OOC with the seabed. Unfocused bottom currents could undergo local acceleration inside the scours, sufficient to prevent the deposition of sediment through the Holocene.
To date, the effect of dense water formation on deep benthic ecosystems in the Gulf of Lions has been only described for DSWC event (Pusceddu et al., 2010, 2012). The rapid sinking of dense water results in important immediate modifications that can be summarized in (i) increased organic matter content in the deep basin; (ii) lower benthic abundance; and (iii) modified benthic biodiversity. At longer time scales the analysis reveals that the Gulf of Lions deep benthic ecosystems is characterized by a very fast (months) recovery after such intrusions (Pusceddu et al., 2012).

Our observations reveal the effect of OOC on POC load in the deep water layer. Inputs of POC exported from the surface layer following the winter 2007-2008 mild OOC or primarily released by resuspended sediments during the winter 2008-2009 deep OOC event may fuel the deep-sea pelagic microorganisms and trigger enhanced biological activity (Boutrif et al., 2012). The POC derived from sediment resuspension is generally much older (up to several thousand years old as described by Tesi et al. $(2008,2010))$ and more refractory than the POC from the downward export of modern marine phytodetritus. The response of deep-sea ecosystems is thus likely dependant on the intensity of OOC that regulate the quantity and quality (i.e., labile vs. refractory) of the POC.

Besides, several studies conducted in other dynamic deep environments around the world indicated that sediment reworking can be ecologically important on the distribution, abundance, and structure of meiofauna associated with the sediment surface (Aller, 1989; Gage et al., 1995; Thistle et al., 1999). Erosional periods can be either beneficial (dispersal enhancement, benthic crowding relief, sediment properties improvement) and detrimental (damaging of animals by removal from the seabed, expatriation, exposure to water predators) to benthic organisms. It is thought that deep OOC events in the Gulf of Lions result in positive or negative effects on the benthos, by fuelling the deep sea floor with large amounts of bioavailable particles or by disrupting the benthic habitats.

\section{Conclusions}

The objective of this 1.5-yr study conducted in the deep basin of the Gulf of Lions (northwestern Mediterranean Sea) was to understand the impact of the open-ocean convection intensity that controls the seasonal variability of the hydrology, hydrodynamics and biogeochemistry of this open-ocean region, on the mid-depth and near-bottom particulate fluxes measured by sediment traps. The major outcomes of this study are

1. Particle fluxes at the different sites between 2050 and 2350-m depth present temporal variations in the $10^{1}-10^{4} \mathrm{mg} \mathrm{m}^{-2} \mathrm{~d}^{-1}$ range. Near-bottom TMF and POC content show coherent temporal variations with a clear 
signal of late winter-early spring maxima. The interannual variability was largely dominated by large fluxes in February-March 2009, which relates to deep OOC. This variability confirms similar patterns previously reported in the Gulf of Lions and in the Ligurian Sea for winters with deep OOC. The discrepancy between the fluxes at mid-depth and near the bottom, and the low POC content close to that of the sediment, observed for the highest fluxes in winter 2008-2009 highlight the role of sediment resuspension by strong currents taking place during the deep OOC.

2. By comparison with previous studies, range and primary origin of near-bottom fluxes are believed to vary according to the deep-water formation intensity from (1) moderate TMF $\left(<1000 \mathrm{mg} \mathrm{m}^{-2} \mathrm{~d}^{-1}\right)$ from a dominant biological source resulting from the surface production export during the winters of shallow OOC; (2) large TMF (up to $10000 \mathrm{mg} \mathrm{m}^{-2} \mathrm{~d}^{-1}$ ) from a dominant sedimentary source due to the remobilization of surface sediment of the deep basin during winters with deep OOC and shallow DSWC; and (3) extreme TMF (>10000 $\mathrm{mg} \mathrm{m}^{-2} \mathrm{~d}^{-1}$ ) from a dominant sedimentary source due to the remobilization of surface sediments from the shelf and slope and mainly from the deep basin during winters with deep OOC and deep DSWC.

3. The observations suggest that the recurrence of deep OOC in the area has a long-term effect on seabed morphology (i.e., by prevention of particle sedimentation) and thus should be considered as a major driving force for deep sedimentary dynamics.

4. Open-ocean deep convection has to be considered, together with dense shelf water cascading, as a major driving force for benthic ecosystems as it occasionally fuels them with labile POC from the surface layer and/or disrupts the benthic habitats by reworking superficial sediment. A better understanding of the composition of the particulate flux (i.e., biogenic and lithogenic contents), and its associated elements (including contaminants) generated by deep OOC events is now required to better assess the impact of such events on benthic ecosystems.

Acknowledgements. We thank the crews of R/V L'Europe, $\mathrm{R} / \mathrm{V}$ Professor Logachev, R/V Suroit and R/V Tethys II for their help and dedication during the cruises. We thank Lars-Eric Heimbürger for valuable comments and language correction. We acknowledge the support of the EU projects SESAME (GOCE-2006-036949), HERMIONE (FP7-ENV-2008-1-226354), the French projects EXTREMA- ANR-06-VULN-005 and LEFE-IDAO-42N5E, and French network MOOSE (Mediterranean Oceanic Observing System in Environment). We thank the referees Tommaso Tesi and Leonardo Langone for their constructive comments which helped to improve the quality of our manuscript. Loic Houpert acknowledges the support of the Direction Générale de l'Armement (supervisor: Elisabeth Gibert-Brunet). The French HydroChanges team acknowledges J. L. Fuda, C. Millot, P. Raimbault, G. Rougier, and the support of the Service d'Observation du COM. This is a contribution to the CIESM HydroChanges Programme (http://www.ciesm.org/marine/programs/hydrochanges.htm).

Edited by: R. Danovaro

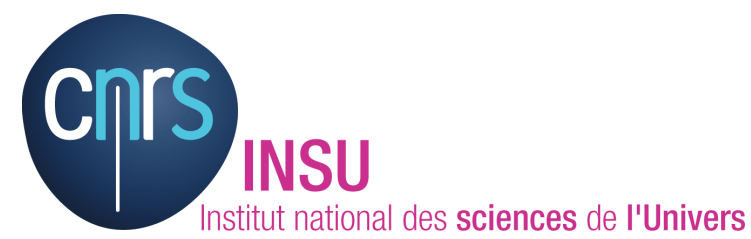

The publication of this article is financed by CNRS-INSU.

\section{References}

Al Ali, B., Garel, M., Cuny, P., Miquel, J.C., Toubal, T., Robert, A., and Tamburini, C.: Luminous bacteria in the deep-sea waters near the ANTARES underwater neutrino telescope (Mediterranean Sea), Chem. Ecol., 26, 57-72, 2010.

Aller, J. Y.: Quantifying sediment disturbance by bottom currents and its effect on benthic communities in a deep-sea western boundary zone, Deep-Sea Res., 36, 901-934, 1989.

Alonso, B., Canals, M., Got, H., and Maldonado, A.: Seavalleys and related depositional systems in the Catalan Sea (Northwestern Mediterranean Sea), AAPG Bull., 75, 1195-1214, 1991.

Amram, P., Anghinolfi, M., Anvar, S., Ardellier-Desages, F. E., Aslanides, E., Aubert, J. J., Azoulay, R., Bailey, D., Basa, S., Battaglieri, M., Bellotti, R., Beltramelli, J., Benhammou, Y., Berthier, R., Bertin, V., Billault, M., Blaes, R., Bland, R. W., Blondeau, F., de Botton, N., Boulesteix, J., Brooks, C. B., Brunner, J., Cafagna, F., Calzas, A., Capone, A., Caponetto, L., Cârloganu, C., Carmona, E., Carr, J., Cartwright, S. L., Cecchini, S., Ciacio, F., Circella, M., Compère, C., Cooper, S., Coyle, P., Cuneo, S., Danilov, M., van Dantzig, R., De Marzo, C., Destelle, J. J., De Vita, R., Dispau, G., Druillole, F., Engelen, J., Feinstein, F., Ferdi, C., Festy, D., Fopma, J., Gallone, J. M., Giacomelli, G., Goret, P., Gournay, J. F., Hallewell, G., Heijboer, A., Hernández-Rey, J. J., Hubbard, J. R., Jaquet, M., de Jong, M., Karolak, M., Keller, P., Kooijman, P., Kouchner, A., Kudryavtsev, V. A., Lafoux, H., Lagier, P., Lamare, P., Languillat, J. C., Laubier, L., Laugier, J. P., Leilde, B., Le Provost, H., Le Van Suu, A., Lo Nigro, L., Lo Presti, D., Loucatos, S., Louis, F., Lyashuk, V., Magnier, P., Marcelin, M., Margiotta, A., Masullo, R., Mazéas, F., Mazeau, B., Mazure, A., McMillan, J. E., Migneco, E., Millot, C., Mols, P., Montanet, F., Montaruli, T., Moscoso, L., Musumeci, M., Nezri, E., Nooren, G. J., Oberski, J. E. J., Olivetto, C., Oppelt-Pohl, A., Palanque-Delabrouille, N., Papaleo, R., Payre, P., Perrin, P., Petruccetti, M., Petta, C., Piattelli, P., Poinsignon, J., Potheau, R., Queinec, Y., Racca, C., Raia, G., Randazzo, N., Rethore, F., Riccobene, G., Ricol, J. S., Ripani, M., Roca-Blay, V., Romeyer, A., Rostovstev, A., Russo, G. V., Sacquin, Y., Salusti, E., Schuller, J. P., Schuster, W., Soirat, J. P., Souvorova, O., Spooner, N. J. C., Spurio, M., Stolarczyk, T., 
Stubert, D., Taiuti, M., Tao, C., Thompson, L. F., Tilav, S., Triay, R., Usik, A., Valdy, P., Valente, V., Varlamov, I., Vaudaine, G., Vernin, P., Vladimirsky, E., Vorobiev, M., de Witt Huberts, P., de Wolf, E., Zakharov, V., Zavatarelli, S., Zornoza, J. d. D., Zúñiga, J., Aloïsi, J. C., Kerhervé, P., and Monaco, A.: Sedimentation and fouling of optical surfaces at the ANTARES site, Astropart. Phys., 19, 253-267, 2003.

Anderson, R. F., Schiff, S. L., and Hesslein, R. H.: Determining sediment accumulation and mixing rates Using ${ }^{210} \mathrm{~Pb},{ }^{137} \mathrm{Cs}$, and other tracers: problems due to postdepositional mobility or coring artifacts, Can. J. Fish. Aquat. Sci., 44, 231-250, 1987.

Auger, P. A.: Modélisation des écosystèmes planctoniques pélagiques en Méditerranée nord-occidentale. Impact des eaux du Rhône à l'échelle du plateau du golfe du Lion et variabilité interannuelle à décennale au large, $\mathrm{PhD}$ Thesis, University of Toulouse, 266 pp., 2011.

Avril, B.: DOC dynamics in the northwestern Mediterranean Sea (DYFAMED site), Deep-Sea Res. Pt. II, 49, 2163-2182, 2002.

Baker, E. T., Milburn, H. B., and Tennant, D. A.: Field assessment of sediment trap efficiency under varying flow conditions, J. Mar. Res., 46, 573-592, 1988.

Berné, S., Loubrieu, B., and CALMAR team: Canyons et processus sédimentaires récents sur la marge du Golfe du Lion occidental, Premiers résultats de la campagne CALMAR, C. R. Acad. Sci. II A, 328, 471-477, 1999.

Béthoux, J. P., Durieu de Madron, X., Nyffeler, F., and Tailliez, D.: Deep water in the western Mediterranean: peculiar 1999 and 2000 characteristics, shelf formation hypothesis, variability since 1970 and geochemical inferences, J. Marine Syst., 33-34, 117131, 2002.

Bonnel, C., Dennielou, B., Droz, L., Mulder, T., and Berné, S.: Architecture and depositional pattern of the Rhône Neofan and recent gravity activity in the Gulf of Lions (western Mediterranean), Mar. Petrol. Geol., 22, 827-843, 2005.

Boutrif, M.: Dégradation de la matière organique dissoute de haut poids moléculaire par les communautés procaryotique des zones méso- et bathypélagique, $\mathrm{PhD}$ thesis, University of AixMarseille, 233 pp., 2011.

Buesseler, K. O.: Do upper-ocean sediment traps provide an accurate record of particle flux?, Nature, 353, 420-423, 1991.

Canals, M.: Estructura sedimantaria y evolución morfológica del talud y el glacis continentales del Golfo de León: fenómenos de desestabilización de la cobertera sedimentaria plio-cuaternaria, PhD thesis, University of Barcelona, 618 pp., 1985.

Canals, M., Puig, P., Durrieu de Madron, X., Heussner, S., Palanques, A., and Fabres, J.: Flushing submarine canyons, Nature, 444, 354-357, 2006.

D'Ortenzio, F. and Ribera d'Alcalà, M.: On the trophic regimes of the Mediterranean Sea: a satellite analysis, Biogeosciences, 6, 139-148, doi:10.5194/bg-6-139-2009, 2009.

Dennielou, B., Jallet, L., Sultan, N., Jouet, G., Giresse, P., Voisset, M., and Berné, S.: Post-glacial persistence of turbiditic activity within the Rhône deep-sea turbidite system (Gulf of Lions, Western Mediterranean): linking the outer shelf and the basin sedimentary records, Mar. Geol., 257, 65-86, 2009.

Dewey, R. K.: Mooring design and dynamics - a Matlab ${ }^{\circledR}$ package for designing and analyzing oceanographic moorings, Marine Models, 1, 103-157, 1999.
Droz, L. and Bellaiche, G.: Rhone deep-sea fan; morphostructure and growth pattern, AAPG Bull., 69, 460-479, 1985.

Droz, L., Kergoat, R., Cochonat, P., and Berné, S.: Recent sedimentary events in the western Gulf of Lions (Western Mediterranean), Mar. Geol., 176, 23-37, 2001.

Durrieu de Madron, X., Castaing, P., Nyffeler, F., and Courp, T.: Slope transport of suspended particulate matter on the Aquitanian margin of the Bay of Biscay, Deep-Sea. Res. Pt. II, 46, 2003-2027, 1999.

Durrieu de Madron, X., Zervakis, V., Theocharis, A., and Georgopoulos, D.: Comments on "Cascades of dense water around the world ocean”, Prog. Oceanogr., 64, 83-90, 2005.

Flynn, W. W.: The determination of low levels of polonium-210 in environmental materials, Anal. Chim. Acta, 43, 221-227, 1968.

Gage, J. D., Lamont, P. A., and Tyler, P. A.: Deep-sea macrobenthic communities at contrasting sites off Portugal, preliminary results: I Introduction and diversity comparisons, Int. Rev. Ges. Hydrobio., 80, 235-250, 1995.

Guidi-Guilvard, L. D.: DYFAMED-BENTHOS, a long time-series benthic survey at 2347-m depth in the Northwestern Mediterranean: general introduction, Deep-Sea Res. Pt. II, 49, $2183-$ 2193, 2002.

Hallden, N. A. and Harley, J. H.: An improved alpha-counting technique, Anal. Chem., 32, 1861-1863, 1960.

Heimbürger, L. E., Cossa, D., Thibodeau, B., Khripounoff, A., Mas, V., Chiffoleau, J. F., Schmidt, S., and Migon, C.: Natural and anthropogenic trace metals in sediments of the Ligurian Sea (Northwestern Mediterranean), Chem. Geol., 291, 141-151, $2012 .$.

Herrmann, M., Somot, S., Sevault, F., Estournel, C., and Déqué, M.: Modeling the deep convection in the northwestern Mediterranean Sea using an eddy-permitting and an eddy-resolving model: Case study of winter 1986-1987, J. Geophys. Res., 113, C04011, doi:10.1029/2006JC003991, 2008.

Herrmann, M., Bouffard, J., and Béranger, K.: Monitoring openocean deep convection from space, Geophys. Res. Lett., 36, L03606, doi:10.1029/2008GL036422, 2009.

Heussner, S., Durrieu de Madron, X., Calafat, A., Canals, M., Carbonne, J., Delsaut, N., and Saragoni, G.: Spatial and temporal variability of downward particle fluxes on a continental slope: lessons from an 8-yr experiment in the Gulf of Lions (NW Mediterranean), Mar. Geol., 234, 63-92, 2006.

Houpert, L., Testor, P., and Durrieu de Madron, X.: Variability of open-sea deep convection and deep water masses in the Northwestern Mediterranean basin over the recent period (2007-2011) from in-situ measurements, Ocean Science Meeting, Salt Lake City, 2012.

Ivanov, V. V., Shapiro, G. I., Huthnance, J. M., Aleynik, D. L., and Golovin, P. N.: Cascades of dense water around the world ocean, Prog. Oceanogr., 60, 47-98, 2004..

Jallet, L. and Giresse, P.: Construction of the PyreneoLanguedocian Sedimentary Ridge and associated sediment waves in the deep Western Gulf of Lions (Western Mediterranean), Mar. Petrol. Geol., 22, 865-888, 2005.

Kenyon, N. H., Millington, J., Droz, L., and Ivanov, M. K.: Scour holes in a channel-lobe transition zone on the Rhône cone, in: Atlas of Deep-water Environments: Architectural Styles in Turbidite Systems, edited by: Pickering, K. T., Hiscott, R. N., Kenyon, N. H., Lucchi, F. R., and Smith, R. D. A., Chapman and Hall, London, 1995. 
Lastras, G., Canals, M., Urgeles, R., Amblas, D., Ivanov, M., Droz, L., Dennielou, B., Fabrés, J., Schoolmeester, T., Akhmetzhanov, A., Orange, D., and García-García, A.: A walk down the Cap de Creus canyon, Northwestern Mediterranean Sea: recent processes inferred from morphology and sediment bedforms, Mar. Geol., 246, 176-192, 2007.

Lévy, M., Mémery, L., and Madec, G.: Combined effects of mesoscale processes and atmospheric high-frequency variability on the spring bloom in the MEDOC area, Deep-Sea Res. Pt. I, 47, 27-53, 2000.

Li, M. Z. and Amos, C. L.: SEDTRANS96: the upgraded and better calibrated sediment-transport model for continental shelves, Comput. Geosci., 27, 619-645, 2001.

López-Jurado, J. L., González-Pola, C., and Vélez-Belchí, P.: Observation of an abrupt disruption of the long-term warming trend at the Balearic Sea, Western Mediterranean Sea, in summer 2005, Geophys. Res. Lett., 32, L24606, doi:10.1029/2005GL024430, 2005.

Madec, G. and Crepon, M.: Thermohaline-driven deep water formation in the Northwestern Mediterranean Sea, in: Elsevier Oceanography Series, edited by: Chu, P. C. and Gascard, J. C., Elsevier, 241-265, 1991.

Marcos, M., Calafat, F. M., Llovel, W., Gomis, D., and Meyssignac, B.: Regional distribution of steric and mass contributions to sea level changes, Global Planet. Change, 76, 206-218, 2011.

Marshall, J. and Schott, F.: Open-ocean convection: observations, theory, and models, Rev. Geophys., 37, 1-64, 1999.

Martín, J., Sanchez-Cabeza, J. A., Eriksson, M., Levy, I., and Miquel, J. C.: Recent accumulation of trace metals in sediments at the DYFAMED site (Northwestern Mediterranean Sea), Mar. Pollut. Bull., 59, 146-153, 2009.

Martín, J., Miquel, J. C., and Khripounoff, A.: Impact of open sea deep convection on sediment remobilization in the western Mediterranean, Geophys. Res. Lett., 37, L13604, doi:10.1029/2010GL043704, 2010.

Marty, J. C. and Chiavérini, J.: Hydrological changes in the Ligurian Sea (NW Mediterranean, DYFAMED site) during 1995-2007 and biogeochemical consequences, Biogeosciences, 7, 21172128, doi:10.5194/bg-7-2117-2010, 2010.

MEDOC Group: Observation of Formation of deep water in the Mediterranean Sea, 1969, Nature, 227, 1037-1040, 1970.

MERMEX Group: Marine ecosystems' responses to climatic and anthropogenic forcings in the Mediterranean, Prog. Oceanogr., 91, 97-166, 2011.

Mertens, C. and Schott, F.: Interannual variability of deepwater Formation in the Northwestern Mediterranean, J. Phys. Oceanogr., 28, 1410-1424, 1998.

Millot, C. and Monaco, A.: Deep intense currents and sedimentary transport in the Northwestern Mediterranean Sea, Geo-Mar. Lett., 4, 13-17, 1984.

Millot, C. and Taupier-Letage, I.: Circulation in the Mediterranean Sea, in: The Handbook of Environmental Chemistry, edited by: Saliot, A., Springer-Verlag, 29-66, 2005.

Miquel, J. C., Martín, J., Gasser, B., Rodriguez-y-Baena, A., Toubal, T., and Fowler, S. W.: Dynamics of particle flux and carbon export in the northwestern Mediterranean Sea: a two decade time-series study at the DYFAMED site, Prog. Oceanogr., 91, 461-481, 2011.
Miralles, J., Radakovitch, O. and Aloisi, J. C.: ${ }^{210} \mathrm{~Pb}$ sedimentation rates from the Northwestern Mediterranean margin, Mar. Geol., 216, 155-167, 2005.

Morel, A. and André, J. M.: Pigment distribution and primary production in the Western Mediterranean as derived and modeled from coastal zone color scanner observations, J. Geophys. Res., 96, 12685-12698, 1991.

Palanques, A., Puig, P., Latasa, M., and Scharek, R., : Deep sediment transport induced by storms and dense shelf-water cascading in the Northwestern Mediterranean basin, Deep-Sea Res. Pt. I, 56, 425-434, 2009.

Palanques, A., Puig, P., Durrieu de Madron, X., Sanchez-Vidal, A., Pasqual, C., Martín, J., Calafat, A., Heussner, S., and Canals, M.: Sediment transport to the deep canyons and open-slope of the Western Gulf of Lions during the 2006 intense cascading and open-sea convection period, Prog. Oceanogr., 106, 1-15, 2012.

Pasqual, C., Sanchez-Vidal, A., Zúñiga, D., Calafat, A., Canals, M., Durrieu de Madron, X., Puig, P., Heussner, S., Palanques, A., and Delsaut, N.: Flux and composition of settling particles across the continental margin of the Gulf of Lion: the role of dense shelf water cascading, Biogeosciences, 7, 217-231, doi:10.5194/bg-7217-2010, 2010.

Puig, P., Palanques, A., Orange, D. L., Lastras, G., and Canals, M.: Dense shelf water cascades and sedimentary furrow formation in the Cap de Creus Canyon, Northwestern Mediterranean Sea, Cont. Shelf Res., 28, 2017-2030, 2008.

Puig, P., Durrieu de Madron, X., Salat, J., Schroeder, K., Martín, J., Karageorgis, A.P., Palanques, A., Roullier, F., Lopez-Jurado, J.L., Emelianov, M., Moutin, T. and Houpert, L.,: Thick bottom nepheloid layers in the western Mediterranean generated by deep dense shelf water cascading. Prog. Oceanogr., in press, 2012.

Pusceddu, A., Bianchelli, S., Canals, M., Sanchez-Vidal, A., Durrieu De Madron, X., Heussner, S., Lykousis, V., de Stigter, H., Trincardi, F., and Danovaro, R.: Organic matter in sediments of canyons and open slopes of the Portuguese, Catalan, Southern Adriatic and Cretan Sea margins, Deep-Sea Res. Pt. I, 57, 441457, 2010.

Pusceddu, A., Mea, M., Gambi, C., Bianchelli, S., Canals, M., Sanchez-Vidal, A., Calafat, A., Heussner, S., Durrieu De Madron, X., Avril, J., Thomsen, L., Garcìa, R., and Danovaro, R.: Ecosystem effects of dense water formation on deep Mediterranean Sea ecosystems: an overview, Adv. Oceanogr. Limnol., 1, 67-83, 2012.

Sanchez-Vidal, A., Pasqual, C., Kerhervé, P., Heussner, S., Calafat, A., Palanques, A., Durrieu de Madron, X., Canals, M., and Puig, P.: Across margin export of organic matter by cascading events traced by stable isotopes, Northwestern Mediterranean Sea, Limnol. Oceanogr., 54, 1488-1500, 2009.

Sanchez-Vidal, A., Canals, M., Calafat, A. M., Lastras, G., PedrosaPàmies, R., Menéndez, M., Medina, R., Company, J. B., Hereu, B., Romero, J., and Alcoverro, T: Impacts on the deep-sea ecosystem by a severe coastal storm, PLoS ONE, 7, e30395, doi:10.1371/journal.pone.0030395, 2012.

Santinelli, C., Nannicini, L., and Seritti, A.: DOC dynamics in the meso and bathypelagic layers of the Mediterranean Sea, DeepSea Res. Pt. II, 57, 1446-1459, 2010.

Santoleri, R., Volpe, G., Marullo, S., and Buongiorno Nardelli, B.: Open waters optical remote sensing of the Mediterranean Sea, in: Remote Sensing of the European Seas, edited by: Barale, V. and 
Gade, M., 103-116, 2008.

Schott, F., Visbeck, M., Send, U., Fischer, J., Tramma, L., and Desaubies, Y.: Observations of deep convection of the Gulf of Lions, Northern Mediterranean, during the winter of 1991/92, J. Phys. Oceanogr., 26, 505-524, 1996.

Somot, S., Sevault, F., Déqué, M., and Crépon, M.: 21st century climate change scenario for the Mediterranean using a coupled atmosphere-ocean regional climate model, Global Planet. Change, 63, 112-126., 2008.

Stemmann, L., Gorsky, G., Marty, J. C., Picheral, M., and Miquel, J. C.: Four-year study of large-particle vertical distribution (0$1000 \mathrm{~m}$ ) in the NW Mediterranean in relation to hydrology, phytoplankton, and vertical flux, Deep-Sea Res. Pt. II, 49, 21432162, 2002.

Testor, P. and Gascard, J. C.: Post-convection spreading phase in the Northwestern Mediterranean Sea, Deep-Sea Res. Pt. I, 53, 869893, 2006.

Tesi, T., Langone, L., Goňi, M. A., Turchetto, M., Miserocchi, S., and Boldrin, A.: Source and composition of organic matter in the Bari canyon (Italy): dense water cascading versus particulate export from the upper ocean, Deep-Sea Res. Pt. I, 55, 813-831, 2008.

Tesi, T., Puig, Palanques, A., and Goňi, M. A.: Lateral advection of organic matter in cascading-dominated submarine canyons, Prog. Oceanogr., 84, 185-203, 2010.
Thistle, D., Levin, L. A., Gooday, A. J., Pfannkuche, O., and Lambshead, P. J. D.: Physical reworking by near-bottom flow alters the metazoan meiofauna of Fieberling Guyot (Northeast Pacific), Deep-Sea Res. Pt. I, 46, 2041-2052, 1999.

Ulbrich, U., Leckebusch, G. C., and Pinto, J. C.: Extra-tropical cyclones in the present and future climate: a review, Theor. Appl. Climatol., 96, 117-131, 2009.

Ulses, C., Estournel, C., Durrieu de Madron, X., and Palanques, A.: Suspended sediment transport in the Gulf of Lions (NW Mediterranean): impact of extreme storms and floods, Cont. Shelf Res., 28, 2048-2070, 2008.

Weliky, K., Suess, E., Ungere, C., Muller, P., and Fischer, K.: Problems with accurate carbon measurements in marine sediments and water column particulates: a new approach, Limnol. Oceanogr., 28, 1252-1259, 1983.

White, J.: The use of sediment traps in high-energy environments, Mar. Geophys. Res., 12, 145-152, 1990.

Wynn, R. B., Kenyon, N. H., Masson, D. G., Stow, D. A. V., and Weaver, P. P. E.: Characterization and recognition of deepwater channel-lobe transition zones, AAPG Bull., 86, 14411462, 2005.

Young, I. R., Zieger, S., and Babanin, A. V.: Global trends in wind speed and wave height, Science, 332, 451-455, 2011. 